Vitenskapelig publikasjon

\title{
Finnmarkskommisjonen justerer kursen
}

Publisert i

TIDSSKRIFT FOR EIENDOMSRETT

ÅRGANG 16, nr. 2-2020, s. 112-142

https://doi.org/10.1826/ISSN.0809-9529-2020-02-02

\section{Øyvind Ravna}

Øyvind Ravna er professor dr. juris ved Det juridiske fakultet, UiT Norges arktiske universitet, Troms $\varnothing$, og professor II ved Samisk høyskole, Kautokeino.

\section{Sammendrag}

Finnmarkskommisjonen er opprettet for å utrede rettigheter til land og vann i Finnmark. Den har i dag fullført seks utredninger. Vurderingene og konklusjonene i de fem første rapportene er så vidt like når det gjelder kollektive rettigheter at de kan sies å være «skåret over samme lest». I desember 2019 la kommisjonen fram sin sjette utredning, rapport felt 4 Karasjok. Denne utredningen bryter i betydelig grad med de foregående, idet kommisjonen for første gang kommer til at folket $\mathrm{i}$ et felt eier sine utmarksområder. I denne artikkelen undersøkes det hvordan kommisjonen kommer til et slikt resultat, hvor det pekes på at det er en følge en annen tilnærming til rettsregler, rettshistorie og folkerett, enn av vesensforskjeller i faktiske forhold.

\section{Nøkkelord}

rettskartleggingen i Finnmark, Finnmarkskommisjonen, eiendomsrett, statens disposisjoner, ILOkonvensjon nr. 169, samerett

\section{Innledning ${ }^{1}$}

Finnmarkskommisjonen har fram til desember 2019 sluttført fem utredningsfelter. Det første utredningen omfattet Stjernøya og Seiland i Altafjorden i Vest-Finnmark og ble framlagt i mars 2012. Den første ble etterfulgt av Nesseby kommune i Øst-Finnmark, Sørøya i VestFinnmark, Varangerhalvøya øst (kommunene Vadsø og Vardø) og Varangerhalvøya vest (kommunene Berlevåg og Båtsfjord) som henholdsvis rapport for felt 2, 3, 5 og 6 i perioden 2013 til 2015. [113]

Vurderingene og konklusjonene i disse fem første rapportene er så vidt like når det gjelder kollektive rettigheter at det som sies for de første rapportene, i alt vesentlig vil være dekkende for de påfølgende. Felles for samtlige utredninger, om man ser bort fra det kuriøse tilfellet Gulgofjord, ${ }^{2}$ er at det ikke anerkjennes kollektive rettigheter utover det som allerede er forankret i finnmarksloven og reindriftsloven. ${ }^{3}$

\footnotetext{
${ }^{1}$ Takk til professor dr. juris Jens Edvin A. Skoghøy og en anonym fagfelle for gjennomlesing og nyttige merknader. ${ }^{2}$ Se Finnmarkskommisjonen, Rapport felt 6 Varanger vest, s. 158-171, hvor kommisjonen kom til at beboerne i Gulgofjord/ Vuođavuotna hadde eiendomsrett til et utmarksområde på $30 \mathrm{~km}^{2}$ da bygda ble fraflyttet i 1970, samt fiskerett i en lokal elv. Som følge av fraflytting var eiendomsretten ikke virksom. Finnmarkseiendommen bestred både eiendomsretten og fiskeretten, noe som ledet til søksmål fra de aktuelle eiere, og at Utmarksdomstolen i sak UTMA2017-62459 kom til at folk i Gulgofjord verken hadde eiendomsrett til det omtvistede området eller fiskerett i elva. ${ }^{3}$ Lov 17. juni $2005 \mathrm{nr}$. 85 om rettsforhold og forvaltning av grunn og naturressurser i Finnmark (finnmarksloven) og lov 15. juni $2007 \mathrm{nr} .40 \mathrm{om}$ reindrift (reindriftsloven).
} 
Den 11. desember 2019 la kommisjonen fram en delutredning for felt 4 Karasjok, hvor den konkluderer med at folket i kommunen eier den tidligere statsgrunnen i kommunen. Denne utredningen bryter i betydelig grad med de foregående, ikke bare fordi kommisjonens flertall konkluderer med at befolkningen i utredningsfeltet har kollektiv eiendoms- og forvaltningsrett til sine naturbruksområder, men også fordi statens tidligere disposisjoner og det historiske faktum vurderes på en annen måte enn i tidligere utredninger.

Problemstillingen for denne artikkelen er å vurdere hva som har foranlediget Finnmarkskommisjonens endrede konklusjoner i 2019, herunder om de har nødvendig rettslig forankring i så vel folkerett som i nasjonal rett. Teksten vil munne ut i en drøfting av den endrede konklusjonens faktiske og rettslige grunnlag, og videre om den er egnet til å ivareta så vel mandatet for rettskartleggingen som denne del av Norges folkerettslige plikter overfor samene. Det gjøres også refleksjoner om Karasjokrapportenes betydning for den videre forvaltning av grunnen i Finnmark.

Reindriftsrettighetene drøftes i liten grad i delutredningen for felt 4. Kommisjonen slår fast at det med grunnlag i alders tids bruk er etablert en alminnelig reindriftsrett innen feltet, og at den ikke vil bli påvirket av endringer i grunneierforholdene. ${ }^{4}$ Vurderingen av reindriftsrettighetene drøftes derfor ikke i denne artikkelen.

Rettskildene til analysen vil primært være finnmarksloven, dens forarbeider samt relevant rettspraksis og folkerett, slik som ILO-konvensjon nr. 169 om urfolk og stammefolk i selvstendige stater av 1989 (ILO 169). Det empiriske materialet som ligger til grunn for undersøkelsen, er Finnmarkskommisjonens utredninger.[114]

\section{Om Finnmarkskommisjonen}

\subsection{Bakgrunn}

Finnmarkskommisjonen er opprettet i 2008 i medhold av finnmarksloven, jf. $§ 5$ tredje ledd, for å utrede rettigheter til land og vann i Finnmark. Så vel loven som kommisjonen er resultat av den samerettslige utviklingen som hadde sitt utspring i Alta-saken, og som bl.a. ledet til at regjeringen Nordli oppnevnte Samerettsutvalget i 1980. ${ }^{5}$ Utvalget foreslo en rekke tiltak for å ivareta hensynet til samisk språk, kultur og levemåte. Sentralt her var forslaget om en lov om grunnforvaltning i Finnmark, hvor det ble foreslått at statens grunn i fylket ble overført til et selvstendig eierorgan, kalt Finnmark grunnforvaltning. Til dette organet skulle Sametinget og

\footnotetext{
${ }^{4}$ Finnmarkskommisjonen, Rapport felt 4, bind 1, s. 216.

${ }^{5}$ Samerettsutvalget ble opprettet ved Kronprinsregentens res. 10. oktober 1980, etter forslag fra Justisdepartementet, se NOU 1984: 18 Om samenes rettsstilling, s. 42.
} 
Finnmark fylkesting oppnevne likt antall representanter til styret. Det ble også foreslått en lokalforankret utmarksforvaltning med utmarksstyrer og adgang til å fastlegge bygdebruksområder. ${ }^{6}$ Finnmarkskommisjonen var imidlertid ikke en del av dette forslaget.

Parallelt med at Samerettsutvalget drøftet en ny forvaltningsordning for grunnen i Finnmark, og at Samerettsutvalgets rettsgruppe vurderte hvem som eide denne grunnen, ${ }^{7}$ ratifiserte Stortinget ILO-konvensjon nr. 169. Det innebar at Norge ikke bare ble rettslig forpliktet til å anerkjenne samenes eiendoms- og råderett over de landområder som de tradisjonelt besitter, men også å ta nødvendige skritt for å kartlegge disse landområdene, og videre sikre effektivt vern av deres eiendoms- og råderett.

Ratifiseringen av ILO-konvensjon nr. 169 var ikke, slik som de øvrige rettsreglene som ble vedtatt av Stortinget for å ivareta samisk kultur, basert på forslag fra Samerettsutvalget. Utvalget mente imidlertid, ut fra en oppfatning om at Indre Finnmark var tradisjonelt samisk område, mens kystområdene i hovedsak var norske, at forslaget oppfylte kravet om eiendomsog besittelsesrett etter ILO 169 artikkel 14 (1) hvis det ble foretatt et rettslig «makeskifte», slik at Finnmark fylkesting og Sametinget fikk lik innflytelse på forvaltningen av hele fylket, og videre at Sametinget ga sitt samtykke til dette. ${ }^{8}$ Videre mente utvalget at dette forutsatte at innbyggerne lokalt «ved sine organer [...] gis innflytelse på bruken av sine goder». ${ }^{9}$

Den foreslåtte ordningen ville således overføre den privatrettslige delen av utmarksforvaltningen til kommuner og bygder. I de samiske kommunene ville dette, [115] fortsatt ifølge Samerettsutvalget, bety at disse sidene av eierrådigheten ble tillagt samiske organer. Utvalget la til grunn at norsk rett som helhet da ville være i samsvar med ILO 169s formål, og at «den form for eiendomsrett til grunnen i Finnmark som vil bli etablert ved opprettelsen av Finnmark grunnforvaltning, vil samsvare med de krav som stilles i artikkel 14 nr. 1 første setning». ${ }^{10}$

Ratifiseringen av ILO 169 bidro til at de faste eiendommer i Finnmark som Statskog SF hadde grunnbokshjemmel til eller eide uten slik hjemmel, ble overført til Finnmarkseiendommen i juli 2006, jf. finnmarksloven $§ 45$. Finnmarkseiendommen (Finnmárkkuopmodat), forkortet $\mathrm{FeFo}$, ble i samme lov definert som et selvstendig

\footnotetext{
${ }^{6}$ NOU 1997: 4 Naturgrunnlaget for samisk kultur, s. 222.

${ }^{7}$ NOU 1993: 34 Rett til og forvaltning av land og vann i Finnmark.

${ }^{8}$ NOU 1997: 4 s. 222, jf. s. 90 hvor det henvises til Folkerettsgruppa i NOU 1997: 5 Urfolks landrettigheter etter folkerett og utenlandsk rett, s. 46-47.

${ }^{9}$ NOU 1997: 4 s. 222.

${ }^{10}$ NOU 1997: 4 s. 93.
} 
rettssubjekt med et styre hvor Sametinget og Finnmark fylkesting hver oppnevner tre av seks styremedlemmer, jf. $\S \S 6$ og 7.

Deler av Samerettsutvalgets lovforslag ble imidlertid ikke videreført av Regjeringen Bondevik i dens forslag til finnmarkslov. Dette gjaldt bl.a. den lokale forvaltningen, noe Sametinget ikke kunne akseptere. ${ }^{11}$ Professorene Hans P. Graver og Geir Ulfstein ble derfor oppnevnt til å foreta en folkerettslig vurdering av forslaget. De kom til at det på viktige punkter ikke oppfylte kravene i ILO $169 .{ }^{12}$ Begrunnet i et ønske om i større grad å sikre en lojal oppfyllelse av ILO 169 foreslo regjeringen på anmodning fra Stortingets justiskomité å opprette en dømmende kommisjon til å identifisere bestående rettigheter i Finnmark. ${ }^{13}$

Etter konsultasjoner med Sametinget og Finnmark fylkesting la justiskomiteens flertall til grunn at rettskartlegging måtte inngå som et sentralt element i finnmarksloven, og at «det skal opprettes en kartleggende kommisjon [Finnmarkskommisjonen] og en dømmende særdomstol [Utmarksdomstolen for Finnmark] for å identifisere bestående rettigheter til land og vann i Finnmark». ${ }^{14}$ Dette ble en del av loven, jf. finnml. $§ 5$ tredje ledd og kapittel 5. Forslaget om lokal forvaltning og mulige bygdebruksområder ble imidlertid ikke tatt med i forslaget, og ble av Sametinget oppfattet som en del av det som skulle avklares gjennom rettskartleggingen. ${ }^{15}$ [116]

\subsection{Mandat}

Finnmarkskommisjonen og rettskartleggingen har som vist en klar forankring i de plikter Norge påtok seg ved å ha ratifisert ILO 169. Dette gjelder i særlig grad artikkel 14 (2) og (3) som pålegger signatarstatene henholdsvis å kartlegge landområder som urfolk tradisjonelt besitter, og å etablere hensiktsmessige ordninger i nasjonal rett for å ta stilling til rettskrav knyttet til landområder fra vedkommende urfolk. ${ }^{16}$

Dette gjenspeiles i kommisjonens mandat, som er å utrede rettigheter til land og vann i Finnmark for å «fastslå omfanget og innholdet av de rettighetene som samer og andre har på grunnlag av hevd eller alders tids bruk eller på annet grunnlag», jf. finnmarksloven $\S 5$. Mandatet er i § 29 første ledd presisert til «på grunnlag av gjeldende nasjonal rett [å] utrede

\footnotetext{
${ }^{11}$ Innst. O. nr. 80 (2004-2005) Om lov om rettsforhold og forvaltning av grunn og naturressurser i Finnmark fylke (finnmarksloven) s. 14.

${ }^{12}$ Hans P. Graver og Geir Ulfstein, «Folkerettslig vurdering av forslaget til ny Finnmarkslov», 3. nov. 2003.

${ }^{13}$ Brev fra Justisdepartementet v/statsråden til justiskomiteen, 14. juni 2004, se Innst. O. nr. 80 (2004-2005) s. 64.

${ }^{14}$ Innst. O. nr. 80 (2004-2005) s. 17.

${ }^{15}$ Sven-Roald Nyst $\varnothing$, tidligere sametingspresident, meddelelse under vitneopptak for Høyesterett, sak HR-2018-456-P (Nesseby), Vads $\varnothing, 10$. oktober 2017, se Øyvind Ravna, Same- og reindriftsrett, Oslo 2019, s. 450.

${ }^{16}$ Innst. O. nr. 80 (2004-2005) s. 28
} 
bruks- og eierrettigheter til den grunnen som Finnmarkseiendommen overtar etter $\S 49 » .{ }^{17} \mathrm{Av}$ forarbeidene framgår det at formuleringen «gjeldende nasjonal rett» er valgt for bedre å få fram at samiske sedvaner og rettsoppfatninger skal hensyntas. ${ }^{18}$

Mandatet må ses i sammenheng med lovens formål, jf. finnmarksloven $\S 1$, samt $\S 3$ som sier at «[1]oven gjelder med de begrensninger som følger av ILO-konvensjon nr. 169 om urfolk og stammefolk i selvstendige stater», og at «[1]oven skal anvendes i samsvar med folkerettens regler om urfolk og minoriteter».

Selv om Høyesterett i HR-2016-2030-A (Stjernøya) har lagt til grunn at inkorporeringen av ILO 169 var ment å begrense seg til finnmarkslovens bestemmelser, og at loven «ikke [regulerer] de materielle reglene som rettighetene skal avklares på grunnlag av» (avsnitt 76), tilsier presumsjonsprinsippet at ILO 169 legger klare føringer på rettskartleggingen og kommisjonens mandat.

\section{Finnmarkskommisjonens fem første utredninger}

\subsection{Rettsanvendelsen}

Vurderingene og konklusjonene i de fem utredningene Finnmarkskommisjonen har sluttført fram til desember 2019, er som nevnt så like når det gjelder kollektive rettigheter at det ikke er nødvendig å gå i dybden på hver enkelt rapport. I det følgende [117] skal vi se på vurderingene som er gjort av bestående rettigheter som samer og andre kan ha på grunnlag av hevd og alders tids bruk, i disse rapportene.

I samtlige rapporter er det konkludert med at Finnmarkseiendommen (FeFo) eier all grunn som omfattes av utredningene i feltene, med unntak av en parsell på 20 dekar i felt 1 og en parsell på 7 dekar i felt 2, samt et utmarksområde på 30 km² i Gulgofjord/Vuođavuotna. ${ }^{19}$ Det er i svært liten grad anerkjent kollektive bruksrettigheter i de fem feltene utover det som alt er lovfestet i finnmarksloven og reindriftsloven. ${ }^{20}$ Førstnevnte lov definerer i $§ \S 22$ og 23 hvilke rettigheter personer bosatt i henholdsvis en kommune (i Finnmark) og i Finnmark har, mens sistnevnte i $\S 4$ første ledd sier at «[d]en samiske befolkningen har på grunnlag av alders

\footnotetext{
${ }^{17}$ Ved lov 21. sep. $2012 \mathrm{nr} .66$ om endringar i deltakerloven, havressurslova og finnmarksloven ble mandatet utvidet til å omfatte utredning av rettigheter til fiskeplasser i sjø- og fjordområder i Finnmark om det framsettes krav om det.

${ }^{18}$ Innst. O. nr. 80 (2004-2005) s. 19.

${ }^{19}$ Se note 2 ovenfor.

${ }^{20}$ I Finnmarkskommisjonen, Rapport felt 5, s. 144-151, konkluderes det med grunnlag i langhevd er ervervet en rett til uttak av grus til husbehov for befolkningen i Skallelv og Komagvær. FeFo har ikke godtatt konklusjonen, men den er ikke brakt videre for rettslig prøving. Som nevnt er det også anerkjent en fiskerett i en mindre elv i felt 6 , men den ble satt til side av Utmarksdomstolen.
} 
tids bruk rett til å utøve reindrift [...] hvor reindriftssamene fra gammelt av har utøvet reindrift (det samiske reinbeiteområdet)».

For alle de fem feltene vurderes kollektive rettigheter til utmarksbeite for bufe, trevirke, torv, fiske, jakt og fangst, egg og dun og bærplukking. I samtlige felt konkluderes det med at disse rettighetene ligger til lokalbefolkningen, og har selvstendig rettsgrunnlag ved siden av loven «på samme måte som allmenningsrettighetene i Sør-Norge har det og på samme måte som reindriftsretten har det i de områdene hvor det har vært drevet reindrift fra gammelt av». ${ }^{21}$ Det heter videre at reglene i finnmarksloven og tidligere lover ikke er av rettsstiftende art, men at de lovfester lokalbefolkningens opprinnelige, sedvanebaserte rettigheter, som i all hovedsak var etablert før staten tok til å disponere over utnyttelsen av rettighetene, og som dermed ikke er ervervet ved hevd eller alders tids bruk etter at statens eierposisjon i de aktuelle delene av Finnmark hadde festnet seg. ${ }^{22}$ Konklusjonene betyr likevel ikke endring i rettsforholdene da rettighetene er «kodifisert i finnmarksloven, og dermed også omfattet av FeFos disponeringshjemler». ${ }^{23}$

At rettighetene er omfattet av FeFos disponeringshjemler, innebærer at lokalbefolkningen ikke kan disponere over rettighetene, slik allmenningsberettigete i andre [118] deler av landet kan. ${ }^{24}$ Skulle de kunne det, måtte de ha rettigheter med et særlig rettsgrunnlag oppstått ved at det $\mathrm{i}$ «alders tid eller full hevdstid er utøvd en bruk som går ut over de rammene som i dag er nedfelt i finnmarksloven». ${ }^{25}$ Dette betyr i praksis at rettigheter etablert før 1775 får et svakere vern mot grunneiers eller det offentliges regulering enn rettigheter ervervet på et senere tidspunkt, og at begrepet «selvstendig rettsgrunnlag» får et mer begrenset innhold enn vanlig i norsk tingsrett.

Året 1775 er stilt opp som et skille ut fra at resolusjonen om jorddelingen i Finnmark, ${ }^{26}$ som angivelig åpnet for at staten kunne utmåle og matrikulere eiendommer til private, da ble vedtatt. Det viser at kommisjonen har lagt til grunn at staten var grunneier på dette tidspunktet, og at resolusjonen la grunnlaget for å etablere private eiendommer i Finnmark. ${ }^{27}$

\footnotetext{
${ }^{21}$ Se eksempelvis Finnmarkskommisjonen, Rapport felt 1, s. 104, og Rapport felt 2, s. 122.

${ }^{22}$ Et unntak fra dette finner man i felt 3 Sørøya på grunn av de spesielle rettighetsforholdene der i middelalderen og Øyas stilling som delvis privateid gods og delvis «Krongods».

${ }^{23}$ Finnmarkskommisjonen, Rapport felt 1, s. 104, og Rapport felt 2, s. 122 m.fl. Se for $\varnothing v$ rig Kirsti Strøm Bull,

«Finnmarksloven - Finnmarkseiendommen og kartlegging av rettigheter i Finnmark», Lov og Rett 2007, s. 545-560, hvor det drøftes hva som ligger i begrensningene i finnmarksloven $\S 5$ andre ledd.

${ }^{24}$ Jf. lov 6. juni $1975 \mathrm{nr}$. 31 om utnytting av rettar og lunnende m.m. i statsallmenningane (fjellova) $§ 3 \mathrm{mfl}$.

${ }^{25}$ Finnmarkskommisjonen, Rapport felt 1, s. 104, og Rapport felt 2, s. 122 m.fl.

${ }^{26}$ Kgl.res. 27. mai 1775 angaaende Jorddelingen i Finmarken samt Bopladses Udvisning og Skyldlægning sammesteds.

${ }^{27}$ Finnmarkskommisjonen, Rapport felt 1, s. 17, og Rapport felt 2, s. 19. I de tre neste rapportene er det nokså like framstillinger.
} 
Med et slik utgangspunkt ble deling og registering av jord og boplasser til disposisjoner hvor staten, i medhold av antatt eiendomsrett, utviste eiendommer til etablering av jordbruk o.a. ${ }^{28}$ Lovgivererkjennelsen av at «[s]amene har kollektivt og individuelt gjennom langvarig bruk av land og vann opparbeidet rettigheter til grunn i Finnmark», jf. finnmarksloven $\S 5$ første ledd, gjenspeiles således i liten grad i rettskartleggingsarbeidet, noe som ikke skyldes manglende oppfyllelse av de alminnelige vilkårene for hevd eller alders tids bruk, men derimot statens disposisjoner (noe jeg kommer tilbake til rett nedenfor).

Rettslig sett er det imidlertid liten grunn til å kritisere Finnmarkskommisjonen da dens konklusjoner er stadfestet av Høyesterett i HR-2018-456-P (Nesseby), se særlig avsnitt 112 og 113. Høyesteretts standpunkt i HR-2018-456-P betyr at lokalbefolkningens rettigheter, til tross for at rettighetene har et selvstendig rettsgrunnlag, ikke nyter det rettsvern som vanligvis ligger til slike rettigheter, eksempelvis mot konkurrerende bruk og grunneiers reguleringer. ${ }^{29}$

\subsection{Særlig om vekten på statens disposisjoner}

For de fem første feltene legger Finnmarkskommisjonen til grunn at lokalbefolkningen har oppfylt bruks- og tidskravet til anerkjennelse av eiendomsrett etter reglene om alders tids bruk. Dette gjøres ved å vise til at beskrivelsen av bruken i Svartskog-dommen langt på vei anses dekkende for bruken i det aktuelle felt. ${ }^{30}$ Den aktuelle beskrivelsen lød slik:

I stikkords form preges bruken av kontinuitet, at den har vært altomfattende og intensiv, og av fleksibilitet. Kravet både til brukens omfang og varighet for erverv av eiendomsrett er etter dette oppfylt (Rt. 2001 s. 1229 på s. 1244).

Kravet er ifølge kommisjonen kun oppfylt «om bruken vurderes isolert». For å få anerkjent eiendomsrett må bruken også vurderes i lys av andres bruk [!]av området og av statens disposisjoner. Videre må det også vurderes om et klart flertall av dem som inngår i den

\footnotetext{
${ }^{28}$ Se også HR-2018-456-P (Nesseby) avsnitt 135 hvor førstvoterende i Høyesterett uttaler at «[s]lik resolusjonen var bygget opp, fremgår det etter mitt syn at den regulerer tildeling og ikke bare registrering av allerede eksisterende rettigheter».

${ }^{29}$ Myndigheter og grunneier har i alminnelighet begrenset disponeringsadgang over slike rettigheter, se f.eks. NOU 2007: 13 s. 398 og 610. På Finnmarkseiendommens grunn blir det motsatt: Det er grunneieren FeFo som i stor grad avgjør om andre enn de bruksberettigete skal få nytte områdene, noe som i en del tilfeller vil begrense deres bruk.

${ }^{30}$ Finnmarkskommisjonen, Rapport Felt 1, s. 64, Felt 2, s. 65, Felt 3, s. 51, Felt 5, s. 54, og felt 6, s. 58, med henv. til Rt. 2001 s. 1229 på s. 1244. Svartskog-dommen (Rt. 2001 s. 1229) er sentral fordi Stortingets justiskomité har pekt på den som en «anvisning på hvordan tradisjonell samisk bruk skal anses som grunnlag for rettserverv», se Innst. O. nr. 80 (2004-2005) s. 36. Dommen gjaldt spørsmålet om staten var eier av et utmarksområde på 116 km² i Manndalen i Kåfjord kommune i Troms, en bygd med en betydelig samisk befolkning. Høyesterett kom til at lokalbefolkningens bruk oppfylte kravene for erverv av eiendomsrett. Til tross for at staten hadde tinglyst sitt rettserverv i 1885, ble også kravet til god tro ansett oppfylt, noe som kan forklares med at Høyesterett tok hensyn til samisk kultur og samiske rettsoppfatninger. Utfallet av saken var at bygdefolket vant fram med krav om eiendomsrett grunnet $\mathrm{i}$ alders tids bruk.
} 
aktuelle brukergruppen, har utøvd sin bruk på grunnlag av en oppfatning av at gruppen er eier av det området hvor bruken har foregått, og ikke bare at man har en bruksrett til dette.

Selv om heller ikke kravet til slik oppfatning blir vurdert å være oppfylt, skal jeg i fortsettelsen konsentrere meg om statens disposisjoner, da det er de som er hovedårsaken til at bygdefolk ikke får anerkjent eiendoms- eller styringsrett til sine utmarksresurser.

Med «statens disposisjoner» siktes det til eierrådighet, faktisk og rettslig, utøvd av statens grunnforvaltere. Offentlig forvaltning og myndighetsutøvelse omfattes således ikke.

Finnmarkskommisjonen har holdt disse statlige disposisjonene i utredningsfeltene opp mot tilsvarende handlinger beskrevet i Svartskog-dommen, og kommet til at de generelt sett er mer omfattende i Finnmark. Sammenlikningen halter imidlertid: I Svartskogen gikk staten aktivt inn i og kjøpte den senere omtvistede eiendommen fra Foreningen til Ophavelse af Leilandingsvaesenet i Skjerv $\phi$, hvoretter [120] rettservervet ble sikret ved tinglysning. ${ }^{31}$ Videre har staten i perioder gitt tydelig uttrykk for sin eierrådighet, bl.a. ved kunngjøringer og oppslag av plakater på kirkebakken og andre beferdede steder. ${ }^{32}$ Staten utstedte dessuten et betydelig antall forpaktningsavtaler for utslåtter, samtidig som søknader om kjøp av jord ble avslått.

I Finnmark har staten ikke noe skjøte på sitt rettserverv, ${ }^{33}$ og staten har heller aldri kunngjort sin eiendomsrett på beferdede steder. Til grunn for finnmarksloven ligger det videre en oppfatning av at staten ikke har opptrådt som en aktiv forvalter i Finnmark. ${ }^{34}$

Oppfatningene om dette er imidlertid til dels delte; Finnmarkskommisjonen viser eksempelvis til at staten har utøvd betydelig aktivitet ved utmål av eiendommer og bortfeste av slåttemark. For felt 2 vises det også til bortfeste av hytte- og gammetomter. ${ }^{35}$

Det er ikke grunnlag for å betvile de faktiske forhold kommisjonen viser til. Likevel kan det spørres om staten har disponert i større grad i eksempelvis Nessebys utmark enn i Svartskogen. At statens disposisjoner framstår som mer omfattende i Nesseby, kan være et resultat av at kommisjonen vurderer statens aktivitet i et felt på hele $1436 \mathrm{~km}^{2}$ uten å ta vesentlige hensyn til at Svartskogen kun dekket $116 \mathrm{~km}^{2}$. Det gås dessuten i liten grad inn på

\footnotetext{
${ }^{31}$ Rt. 2001 s. 1229 på s. $1232-1233$.

${ }^{32}$ Rt. 2001 s. 1229 på s. 1247-1250, hvor det også framgår at det ble opplyst at det var forbudt å avvirke skog og høste slåtter uten statens tillatelse, og at brudd ble fulgt opp av politianmeldelser av ulovlig slått på statens eiendom.

${ }^{33}$ Jeg ser da bort fra det fiktive skjøtet som ble utstedt da staten v/Landbruksdepartementet overførte eiendomsretten til grunnen i Finnmark til Statskog SF i 1993, se Øyvind Ravna, «Retten til jorden i Finnmark, samenes rettigheter og forslaget til Finnmarkslov», Kritisk juss 2/2005 (vol 31), s. 200-211 på s. 205.

${ }^{34}$ I Ot.prp. nr. 53 (2002-2003) s. 13 beskrives statens disposisjoner som tilbakeholdne.

${ }^{35}$ Finnmarkskommisjonen, Rapport felt 1, s. 67, og Rapport felt 2, s. 68. På s. 62 (felt 2) viser kommisjonen bl.a. til et dokumentutdrag fremlagt av FeFo, som synliggjør at statens forpaktningspraksis strekker seg tilbake til 1860-tallet. Dette utdraget, som gjelder utmål av ca. 210 utmarksslåtter i perioden fram til 1920, har stått sentralt i vurderingen av statens disposisjoner, og har dermed bidratt til at lokalbefolkningen ikke får anerkjent eksklusive bruksrettigheter.
} 
bruken av de enkelte spesifikke områdene, slik som naturlig avgrensede dalfører o.l., og dermed områder som kunne sammenliknes med Svartskogen (og Manndalen i Troms).

Graden av statens disposisjoner kan således drøftes. Det som derimot ikke trenger å drøftes, er om statens rolle, som myndighetsutøver og grunneier på samme tid, har vært uklar. ${ }^{36}$ Det har gjort det vanskelig for folk i fylket å skille mellom disse rollene, herunder å se de rettslige følgene av statens disposisjoner. Et eksempel på slik sammenblanding er at politimesterembetet i Vads $\varnothing$ utstedte forpaktningsbrev på vegne [121] av staten. ${ }^{37}$ Slike uklarheter og sammenblandinger kunne tilsi mindre vekt på statens disposisjoner.

Selv om det foreligger grundige sakkyndige utredninger, ${ }^{38}$ har kommisjonen i liten grad lagt vekt på hvilke rettsoppfatninger lokalbefolkningen har hatt om de statlige disposisjonene. Ut fra betydningen statens disposisjoner har fått, kunne man forvente at oppfatningene rundt disse disposisjonene, f.eks. om de ble sett på som eierdisposisjoner eller myndighetsutøvelse, i større grad kunne vært undersøkt. Det kunne videre også ha vært unders $\varnothing$ kt om bygdefolk har oppfattet forpaktningsbrev og liknende dokumenter som etablering av leieforhold, eller som bekreftelse på en rett de hadde, og som dermed bidro til å beskytte bruken av deres tradisjonelle slåtter o.a. mot konkurrerende bruk.

I Svartskog-dommen konkluderte Høyesterett med at 14 avtaler om slåtteforpaktninger med staten i 1921 og 5 tilsvarende i 1928 ikke rokket ved lokalbefolkningens gode tro. Det samme var tilfellet for avslag på søknader om jord til dyrkingsformål i $1935 .{ }^{39}$ Graden av høsting av utmarksslåtter uten forpaktningsavtaler i utredningsfeltene synes heller ikke å være drøftet i vesentlig grad, idet det verken framgår i hvilket omfang dette har skjedd, eller om staten motsatte seg slik høsting. ${ }^{40}$

Fravær av så vel skriftspråk som norskkunnskaper er blant de forhold Høyesterett i Selbuog Svartskog-dommen framholder som særlige metodespørsmål, hvor det uttales at det må «tas hensyn til at det i kommunikasjon mellom nordmenn og samer kan oppstå misforståelser

\footnotetext{
${ }^{36}$ Ot.prp. nr. 53 (2002-2003) s. 13. Se også Øyvind Ravna, «Rettskartleggingen i Finnmark og reglene om alders tids bruk», Tidsskrift for Rettsvitenskap 2015, s. 53-90.

${ }^{37}$ Forpaktningsbrev nr. 150, J.no 6767 1901, approbert 1. nov. 1901, framlagt av FeFo for utredning av felt 2 Nesseby. At politimesteren utstedte slike eiendomsdokumenter, noe som naturlig er en del grunneiers disposisjoner, gjør at mottakere ikke nødvendigvis har oppfattet dette som eierrådighet.

${ }^{38}$ NIKU, Felt 1 Stierdná/Stjernøya og Sievju/Seiland Oppdragsrapport 42 (2011) og Felt 2 Unjárgga gielda / Nesseby kommune, Oppdragsrapport 43 (2011).

${ }^{39}$ Rt. 2001 s. 1229 på s. $1248-1249$.

${ }^{40}$ Finnmarkskommisjonen, Rapport felt 1, s. 62, hvor det heter: «Imidlertid kan det ha forekommet noe slåttebruk uavhengig av dette», og Rapport felt 2, s. 62, hvor det vises til Øystein Nilsen, Varangersamene (2009), s. 45-46, om at «[i]kke alle hadde papirene i orden», og Hans Prestbakmo, «Bruken av utmarksressursene i Finnmark i dette århundret», i NOU 1994: 21 s. 168-169, som skriver: «I Nesseby fortelles at bare en del av slåttene var utmålt, men at slåttene blei høsta etter gammel sedvane», og at «en informant forteller at myrene som var viktige slåttemarker, var delt og at hver hadde sitt uten at det var noe utmål på dette».
} 
fordi språklige og kulturelle forskjeller kan medføre at man oppfatter hverandre på en uriktig måte». ${ }^{41}$ Det framgår ikke i hvilken grad det som trolig kunne tilsi mindre vekt på statens disposisjoner på 1800- og tidlig på 1900-tallet, er hensyntatt av Finnmarkskommisjonen. Gås det 100 år tilbake i tid, kan det eksempelvis for Nesseby vises til at få av herredets innbyggere behersket norsk. ${ }^{42}[\mathbf{1 2 2}]$ Dette innebærer at samisk kultur og samiske rettsoppfatninger, herunder regler om uformell forvaltning av utmarksbruken, fortsatt må ha vært høyst levende. Videre kan det spørres om den samiske allmuen var i stand til å forstå forskrifter, forpaktningsbrev o.l. Talende er Amund Hellands uttalelse om at «[d]et er yderst faa [av samene], som med udbytte kan læse en norsk avis». ${ }^{43}$ For $\varnothing v$ rig kunne fornorskingspolitikken, og det syn den frambrakte på samisk kultur, tilsi en ytterligere varsomhet med å ilegge statens disposisjoner tung vekt.

Det kunne også vært undersøkt i hvilken grad staten har opptrådt $i$ strid med bygdefolks interesser, f.eks. ved å motsette seg jordutmåling og ved å hindre hogst til husbruk, noe som kan sies å være en forutsetning for å fortrenge bygdefolks rett. ${ }^{44}$ Antakelig har det skjedd i liten grad. Likevel konkluderes det med at statens disposisjoner over tid har «medført at det er etablert en rett for staten til å styre ressursutnyttelsen [...] når dette har vært nødvendig for å sikre ressurstilgangen og fremme en ordnet bruk». ${ }^{45}$

Det er således ikke manglende kontinuitet eller intensivitet $\mathrm{i}$ bruken som har stått i veien for anerkjennelse av bruks- eller eierrettigheter i utredningsfeltene i Finnmark; den er «tilstrekkelig langvarig og sammenhengende til å være potensielt rettsstiftende» i alle de utredede feltene. ${ }^{46}$ Det er heller ikke andres bruk, men derimot statens disposisjoner som har skapt en uoverstigelig terskel for anerkjennelse av slike rettigheter; ${ }^{47}$ rettigheter av en art som innebærer at lokalbefolkningen selv kan delta i forvaltningen av sine utmarksressurser. Selv om Høyesterett i HR-2018-456-P (Nesseby), avsnitt 112-117, ikke fant dette problematisk,

\footnotetext{
${ }^{41}$ Rt. 2001 s. 769 på s. 792 og Rt. 2001 s. 1229 på s. 1249.

${ }^{42}$ Amund Helland, Norges land og Folk: Finmarkens Amt, bind II (1906), s. 14, hvor det framgår at det i Nesseby, innbefattet Polmak, på dette tidspunkt var 1512 innbyggere. Av disse var hele 1262 personer eller 83,5 prosent samer. Blant disse var det kun 9 norsktalende. Hellands beskrivelse viser også at Nesseby på denne tiden var Finnmarks største sameherred med nesten like mange samiske innbyggere som Karasjok og Kautokeino til sammen.

${ }^{43}$ Helland, Norges land og Folk: Finmarkens Amt, bind II (1906), s. 150.

${ }^{44}$ Tønnesen, Retten til jorden i Finnmark, s. 183.

${ }^{45}$ Finnmarkskommisjonen, Rapport felt 2, s. 122. Konklusjonene er senere gjentatt i Rapport felt 3, s. 93, hvor «etablert» er byttet ut med «opprettholde», og i Rapport felt 5, s. 111, hvor begrepet «etablere og opprettholde» er nyttet. I Rapport felt 6, s. 105, gjentas formuleringen i Rapport felt 5.

${ }^{46}$ Finnmarkskommisjonen, Rapport felt 1, s. 61, Rapport felt 2, s. 61, Rapport 3, s. 46, Rapport felt 5, s. 48, og Rapport felt 6, s. 49, hvor bruken framholdes som «åpenbart [...] tilstrekkelig». Jf. også Rapport felt 1, s. 64, og Rapport felt 2, s. 65, når det gjelder intensitet i bruken. De tre øvrige rapportene har liknende formuleringer.

${ }^{47}$ Finnmarkskommisjonen, Rapport felt 1, s. 64, og Rapport felt 2, s. 65. De tre påfølgende rapportene har liknende formuleringer.
} 
kan det spørres om formodningen i finnmarksloven $\S 5$ første ledd, om anerkjennelse av rettigheter opparbeidet av samer, dermed er oppfylt.

Kommisjonen stiller dessuten, med henvisning til Svartskog-dommen, krav om utøvelse av «aktiv styring over ressursbruken» for å få anerkjent rettigheter utover det [123] som er regulert i finnmarksloven. ${ }^{48}$ Dokumentasjon av slik styring, som er sedvanebasert, muntlig formidlet og avgrenset til nødvendige regler om ressursfordeling, vil i praksis være svært krevende, om ikke området, slik som i Svartskogen, har vært gjenstand for en rekke konflikter og tvister som setter sine spor i arkiver. Resultatet blir dermed at kommisjonen for samtlige felter viser til Høyesteretts beskrivelse av styringen av Svartskogen, hvoretter det påpekes:

Det er ikke noe i det materialet som er fremskaffet eller er lagt frem for kommisjonen, som tyder på at befolkningen i hele eller deler av [Nesseby kommune] frem mot vår tid har utøvd en form for styring med den lokale ressursutnyttelsen som kan sammenliknes med dette. ${ }^{49}$

Synspunktet om at folk i utredningsfeltene i langt mindre grad enn folk i Manndalen har forvaltet sine nærliggende naturressurser, er avgjørende for at rett til styring og forvaltning ikke anerkjennes i HR-2018-456-P (Nesseby) avsnitt 142-149.

\section{Finnmarkskommisjonens rapport for felt 4 Karasjok}

\subsection{Folk i utredningsfeltet har kollektiv eiendomsrett}

Den 11. desember 2019 la Finnmarkskommisjonen fram første del av utredningen for felt 4 Karasjok. Kronologisk er dette kommisjonens sjette rapport. Den er fremlagt mer enn fire år etter den forrige rapporten, felt 6 Varangerhalvøya vest, som ble fremlagt i oktober 2015. I denne perioden har ett av kommisjonens juridiske medlemmer fratrådt og blitt erstattet av et annet, ${ }^{50}$ samtidig som kommisjonen har lagt bak seg et betydelig arbeid. Det vises ikke bare ved at delutredningen teller hele 676 sider fordelt på to bind, men også ved at utredningen, som ble startet i 2011, har tatt innpå ni år. Til sammenlikning ble de fem forutgående utredningene gjennomført i løpet av knappe sju år. Også diskusjonene internt i kommisjonen antas å ha vært flere og mer omfattende, da hovedkonklusjonen for første gang er avsagt under dissens (3 mot 2).

\footnotetext{
${ }^{48}$ Finnmarkskommisjonen, Rapport felt 1, s. 66, Rapport felt 2, s. 68, Rapport felt 3, s. 54, Rapport felt 5, s. 58, og Rapport felt 6, s. 64.

${ }^{49}$ Finnmarkskommisjonen, Rapport felt 2, s. 68. Sml. Rapport felt 1, s. 67, Rapport felt 3, s. 54, Rapport felt 5, s. 58, og Rapport felt 6, s. 64, hvor samme formulering er nyttet.

${ }^{50}$ John Bernhard Henriksen tiltrådte som medlem 20. oktober 2015,

https://www.domstol.no/finnmarkskommisjonen/om-kommisjonen/medlemmer-og-ansatte (20.05.2020).
} 
I delutredningen for Karasjok konkluderes det med at folket bosatt i kommunen i fellesskap er eiere av grunnen som i 2006 ble overført fra Statskog SF til FeFo. Dette er første gang kommisjonen har kommet til at folk i Finnmark har kollektiv eiendoms- og forvaltningsrett til sine tradisjonelle naturbruksområder.[124]

I likhet med i tidligere utredninger viser kommisjonen til Svartskog-dommen, hvor Høyesterett beskriver bruken i tvisteområdet som preget «av kontinuitet, at den har vært altomfattende og intensiv, og av fleksibilitet. Kravet både til brukens omfang og varighet for erverv av eiendomsretter er etter dette oppfylt». ${ }^{51}$ Kommisjonen legger til grunn at denne beskrivelsen også anses dekkende for lokalbefolkningens bruk av utmarka i Karasjok med hensyn til kontinuitet og fleksibilitet. Som i tidligere utredninger peker kommisjonen på at spørsmålet om befolkningen har kollektive eier- eller bruksrettigheter til området, ikke bare beror på befolkningens bruk, men også på andres bruk og statens disposisjoner.

Men i motsetning til i tidligere rapporter legges det (enstemmig) til grunn at folket $\mathrm{i}$ området i mange hundre år har brukt og rådet over naturressursene i området på en måte som i det vesentlige tilsvarer det å inneha kollektiv eiendomsrett. ${ }^{52}$ Spørsmålet er således ikke om befolkningen skal «få anerkjent eiendomsrett til et område». ${ }^{53}$ Det er derimot om etablerte rettigheter er i behold, eller om statens angivelige eierrådighet i årene fra 1751 fram til 1980 er blitt til et festnet rettsforhold som tilsier at staten var grunneier da grunnen ble overført til FeFo. ${ }^{54}$

Videre må det vurderes om den lokale bruken har hatt grunnlag i en rettsoppfatning som korresponderer med kollektiv eiendomsrett eller kollektiv bruksrett, og at

det herunder må vurderes hvilken betydning statens disposisjoner har for dagens rettighetsforhold, og om disposisjonene har virket inn på de lokale rettsoppfatningene på en måte som har gjort at den opprinnelige lokale retten har endret karakter, eller falt bort. ${ }^{55}$

Dette bærer bud om et noe mer nyansert blikk på betydningen av statens disposisjoner enn i tidligere utredninger.[125]

\footnotetext{
${ }^{51}$ Finnmarkskommisjonen, Rapport felt 4, bind 1, s. 154, med henv. til Rt. 2001 s. 1229 på s. 1244.

${ }^{52}$ Finnmarkskommisjonen, Rapport felt 4, bind 1, s. 118 og 154.

${ }^{53}$ Slik uttrykt i Finnmarkskommisjonen, Rapport felt 2, s. 65.

${ }^{54}$ Finnmarkskommisjonen, Rapport felt 4, bind 1, s. 118, s. 154 og 218. At sluttstrek for vektlegging av staten disposisjoner er satt til 1980, ligger i at da ble Samerettsutvalget oppnevnt, noe som var en statlig erkjennelse av at deler av Finnmark kan ha andre eiere enn staten, og dermed en fristavbrytende omstendighet, se bind 1, s. 187-188.

${ }^{55}$ Finnmarkskommisjonen, Rapport felt 4, bind 1, s. 154 (uth. av kommisjonen).
} 


\subsection{Vekten på statens disposisjoner}

Karasjokutredningen skiller seg i betydelig grad fra tidligere utredninger når det gjelder vurderingen av statens disposisjoner. I drøftingen av disse viser Finnmarkskommisjonen først til at FNs spesialrapportør for urfolks rettigheter, Victoria Tauli-Corpuz, har uttalt seg kritisk til kommisjonens konklusjoner i de første fem feltene. Det vises her til at spesialrapportøren har pekt på at konklusjonene i stor grad ser ut til å være et resultat av vektlegging av statens aktive og omfattende disposisjon over land og ressurser i de utredede feltene, noe som ser ut til å ha utelukket eier- eller bruksrettigheter for lokalbefolkningen. Spesialrapportøren uttaler etter dette at statens tidligere disposisjoner som antatt eier av grunnen i Finnmark ikke kan vektlegges for å begrunne et fortsatt eierskap til land. ${ }^{56}$

Etter en gjennomgang av norsk rettspraksis, og da særlig HR-2018-456-P (Nesseby) hvor Høyesterett, uten å vise til spesialrapportørens uttalelse, legger betydelig vekt på statens disposisjoner, uttaler kommisjonen at slike disposisjoner må trekkes inn i vurderingen på «vanlig måte». Mer konkret må det gjøres «en bred vurdering der 'lokalbefolkningens handlemåte og oppfatninger' holdes opp mot statens (og andres) disposisjoner». ${ }^{57}$ Med dette som utgangspunkt vurderer kommisjonen statens disposisjoner i felt 4.

Som vist har kommisjonen lagt til grunn at da området ble underlagt Danmark-Norge i 1751, hadde folket i området en rett som i det vesentlige tilsvarer kollektiv eiendomsrett, og at spørsmålet dermed blir om denne retten er i behold, eller om statens disposisjoner og antatte eiendomsrett fra 1751 fram til 1980 tilsier at staten var grunneier da grunnen ble overført til FeFo. ${ }^{58}$ Dette er for $\varnothing v$ rig et spørsmål Høyesterett tidligere har avvist som ikke-treffende. ${ }^{59}$

En samlet kommisjon slår innledningsvis fast at de historiske kildene viser at staten i liten grad har disponert privatrettslig over grunn og ressurser i dagens Karasjok kommune fra 1751 og fram mot slutten av 1800-tallet. Det vises her til at de oppmålinger som da har funnet sted,

\footnotetext{
${ }^{56}$ Finnmarkskommisjonen, Rapport felt 4, bind 1, s. 184, med henv. til «Report of the Special Rapporteur on the rights of indigenous peoples on the human rights situation of the Sami people in the Sápmi region of Norway, Sweden and Finland», 9. august 2016, avsnitt 23 og 24 (min oversetting). Spesialrapportøren forankret sitt standpunkt i FNs erklæring om urfolks rettigheter artikkel 26 (3) og ILO-konvensjon nr. 169 artikkel 8 (1).

${ }^{57}$ Finnmarkskommisjonen, Rapport felt 4, bind 1, s. 186.

${ }^{58}$ Finnmarkskommisjonen, Rapport felt 4, bind 1, s. 118 og 218.

${ }^{59}$ I HR-2018-456-P (Nesseby), avsnitt 146, påpekes det at dette ikke er en treffende spørsmålsstilling «verken rettslig eller ut fra de faktiske forholdene i saken». Høyesteretts standpunkt hadde sin bakgrunn i at Utmarksdomstolen for Finnmark, i sak 2014-164739 (dom 23. januar 2017) punkt 8.3, svarte benektende på spørsmål (reist i punkt 3), «om staten, slik Finnmarkskommisjonen har kommet til, gjennom disse handlingene [disposisjoner over grunnen og som en regulerende makt gjennom lovgivning og forvaltningshandlinger] overtok styringsretten over bruksrettighetene knyttet til utmarksressursene i tvisteområdet».
} 
hvor de eldste skriver seg tilbake til 1811-1814, da det ble målt opp og skyldsatt ti eiendommer i Ávjovárri/ Karasjok, i all hovedsak var formaliseringer av etablert bruk. ${ }^{60}$

Det ble oppmålt et betydelig antall eiendommer etter at lov 22. juni 1863 om avhendelse av Statens jord i Finmarkens Landdistrict trådte i kraft. ${ }^{61}$ Etter en inngående gjennomgang av disse legger kommisjonen til grunn at dette i all hovedsak er oppmåling og skyldsetting av allerede etablerte eiendommer, ${ }^{62}$ hvor utmålingen da ikke er uttrykk for statlig eierrådighet. Den setter deretter søkelys på perioden 1902 til $1965 .{ }^{63}$ I denne perioden ble det etablert 771 eiendommer i Karasjok, ${ }^{64}$ noe som ifølge kommisjonen viser at statens disposisjoner over grunn og ressurser i Karasjok $\varnothing$ kte betraktelig i omfang etter $1902 .{ }^{65}$ Statens privatrettslige rådighetsutøvelse over grunnen som ikke har vært utmålt og solgt til private, var imidlertid beskjeden:

Staten bortforpaktet, særlig fra tidlig på 1900-tallet og frem til 1945, relativt mange utmarksslåtter. En del av forpaktningene var imidlertid trolig formaliseringer av alt etablert bruk. For $\emptyset$ vrig har staten bare gjort et fåtall mer typiske privatrettslige disposisjoner over den usolgte grunnen i Karasjok. ${ }^{66}$

Dernest drøfter kommisjonen hvilke rettsoppfatninger lokalbefolkningen kan ha hatt om bruken. Også her vises det til Svartskog-dommen, hvor det ikke fikk avgjørende betydning at 14 personer i 1921 hadde inngått avtaler med staten om slåtteforpaktning, da det ifølge Høyesterett ikke kunne ikke «anses som bevis for at disse personene aksepterte at de var uten rettigheter i Svartskogen. Årsaken kan like gjerne være [127] at de lettere enn andre bøyde seg for et pålegg fra myndighetene, eller at de så fordeler i å få seg tildelt en bestemt teig». ${ }^{67}$ Det fikk heller ikke avgjørende betydning at fem personer hadde inngått slike avtaler i 1928, eller at det på 1940-tallet ble inngått avtaler om hogst og slåttebruk mellom bygdefolk og staten. ${ }^{68}$

Finnmarkskommisjonen legger deretter til grunn at også i Karasjok kan noen ha ansett det som fordelaktig å få formalisert sin pågående bruk eller å få tildelt et eget grunnstykke eller

\footnotetext{
${ }^{60}$ Finnmarkskommisjonen, Rapport felt 4, bind 1, s. 164, jf. s. 192.

${ }^{61}$ Finnmarkskommisjonen, Rapport felt 4, bind 1, s. 166, hvor det vises til at det $\mathrm{i}$ «de snaue 40 årene 1863-loven regulerte jordutmålingene, ble det etablert 144 eiendommer i Karasjok som kan gjenfinnes i dagens matrikkel». Kommisjonen peker på at 1863-loven er første gang «statens jord» nyttes i en norsk lov, Rapport felt 4, bind 1, s. 165, med videre henv. til Gudmund Sandvik i NOU 1993: 34 s. 334 f. på s. 337.

${ }^{62}$ Finnmarkskommisjonen, Rapport felt 4, bind 1, s. 164.

${ }^{63}$ Dette var perioden da lov 22. mai 1902 nr. 7 om Afhændelse af Statens Jord og Grund i Finmarkens Amts Landdistrict var virksom. Den ble etterfulgt av lov av 12. mars 1965 om statens umatrikulerte grunn i Finnmark fylke.

${ }^{64}$ Finnmarkskommisjonen, Rapport felt 4, bind 1, s. 168. Av disse var det 160 festetomter og punktfester.

${ }^{65}$ Finnmarkskommisjonen, Rapport felt 4, bind 1, s. 170. Betydningen av disse drøftes nærmere i punkt 5.3 nedenfor.

${ }^{66}$ Finnmarkskommisjonen, Rapport felt 4, bind 1, s. 198-199.

${ }^{67}$ Finnmarkskommisjonen, Rapport felt 4, bind 1, s. 198, med henv. til Rt. 2001 s. 1229 på s. 1248.

${ }^{68}$ Finnmarkskommisjonen, Rapport felt 4, bind 1, s. 198, med henv. til Rt. 2001 s. 1229 på s. 1249 og 1251.
} 
slåtteområde. At festeavgiftene var relativt lave, kan ha bidratt til at slik formalisering ikke utgjorde noen stor $\varnothing$ konomisk belastning. Kommisjonen legger med dette vesentlig større vekt på rettsoppfatninger som ble uttrykt i Svartskog-dommen, enn tidligere. ${ }^{69}$ Oppfatningen om at statens grunneierrelaterte disposisjoner har vært av beskjedent omfang, og måten lokalbefolkningens rettsoppfatninger er vurdert, skiller seg således i betydelig grad fra tidligere utredninger. ${ }^{70}$

Videre drøfter kommisjonen usikkerheten knyttet til at statlige jordavhendinger opprinnelig ble ansett å ha grunnlag i Kongens privatrettslige eiendomsrett. Etter eldre norsk allmenningsrett var ikke Kongen «eneeier» av allmenningsgrunnen, men rettighetshaver sammen med de $\varnothing$ vrige allmenningsberettigede. ${ }^{71} \mathrm{Ut}$ fra dette legges det til grunn at avhendinger av allmenningsjord ikke nødvendigvis skjedde i kraft av en opprinnelig eiendomsrett, men var utslag av en styringsrett med grunnlag i et kongelig privilegium. ${ }^{72}$

Kommisjonen skriver i fortsettelsen at «[d]e statlige disposisjonene over den usolgte grunnen i Karasjok var beskjedne i innhold og omfang, og kan derfor ha latt seg forstå innenfor rammene av en privilegie-tenkning». ${ }^{73}$ Videre vises det til at det i[128]nyere tid er reist tvil om statens eiendomsrett til deler av grunnen i Finnmark, bl.a. da mandatet til Samerettsutvalget ble utformet i 1980, og i forarbeidene til finnmarksloven, hvor det uttales at $\mathrm{i}$ alle fall «deler av indre Finnmark» er områder som «samene har krav på eiendoms- og besittelsesrett til». ${ }^{74}$

I en helhetsvurdering må statens disposisjoner holdes opp mot lokalbefolkningens bruk og disposisjoner. Kommisjonen viser her til at Karasjok-folket i hele perioden etter 1751 har utøvd en omfattende, intensiv og mangesidig bruk av de lokale utmarksressursene:

\footnotetext{
${ }^{69} \mathrm{Sml}$. det som er gjennomgått i punkt 3.2 (s. 121-123).

${ }^{70} \mathrm{Sml}$. Øyvind Ravna, «Rettskartleggingen i Finnmark og reglene om alders tids bruk», Tidsskrift for Rettsvitenskap 2015, s. 53-90 på s. 78-79, hvor vurderinger av den art som her gjøres, etterspørres nå det gjelder felt 2 Nesseby.

${ }^{71}$ Finnmarkskommisjonen, Rapport felt 4, bind 1, s. 198, med henv. til Thor Falkanger, Almenningsrett, 2009 , s. 46.

${ }^{72} \mathrm{Om}$ «avhending» er et treffende begrep kan det settes spørsmål ved, og i den grad det var det, var det ganske sikkert et utslag av et kongelig privilegium (her kunne kommisjonen med fordel ha vist til Christian 5s. Norske lov av 1687 , art. 3-12-4 som ga Kongen hjemmel for denne styringsretten, hvor det het at «Kongens Foget skal ikke bortbygge nogen Plads i Almindingen med mindre den ved lovlig Besigtelse befindis at kunde med Tiden opryddis til et Skatteboel»). Vel så sannsynlig er det at det som fant sted var oppdeling av jordfellesskap, og ikke avhending, se Øyvind Ravna, «Den tidligere umatrikulerte grunnen i Finnmark: Jordfellesskap fremfor statlig eiendom?», Tidsskrift for Rettsvitenskap 2020, s. 219-263.

${ }^{73}$ Finnmarkskommisjonen, Rapport felt 4, bind 1, s. 199. Med henv. til Håvard Steinsholt, Oreigning, Hans Sevatdal, v/Per Kåre Sky og Erling Berge (red.), Eigedomshistorie. Hovudliner i norsk eigedomshistorie frå 1600-talet fram mot nåtida, 2017, viser kommisjonen (på s. 32) til at: «På denne tiden kunne kongemakten nokså fritt gripe inn i private rettigheter. Ideen om ekspropriasjonserstatning ble for eksempel ikke formulert før på slutten av 1600-tallet, og fikk ikke umiddelbart gjennomslag.»

${ }^{74}$ Finnmarkskommisjonen, Rapport felt 4, bind 1, s. 43 og s. 205, med henv. til Ot.prp. nr. 53 (2002-2003) s. 88.
} 
Denne bruken tilsvarer i innhold og omfang den bruken innehaveren av en kollektiv eiendomsrett til de aktuelle områdene vil ha utøvd. Det fremgår også at befolkningen har utøvd betydelig grad av egenforvaltning med ressursutnyttelsen, ved at det har vært i funksjon ulike interne fordelingsordninger for blant annet slåttemark, multeplukking og fiskevann. ${ }^{75}$

Det legges deretter til grunn at Karasjok-befolkningens bruk har vært dominerende fram til de første tiårene etter andre verdenskrig: «I denne perioden utøvde befolkningen, med unntak av bruken av skogen, også betydelig styring over den lokale ressursutnyttelsen.» ${ }^{76}$ Det vises så til Svartskog-dommen, hvor de rettsoppnevnte sakkyndige uttalte at Svartskogen hadde status som «bygdeallmenning for alle bosatte i Manndalen og som folk i hovedsak har forvaltet på egen hånd. Den måten dette har skjedd på, uten noe formelt styre, og med så omfattende bruk over tid og fremdeles svært aktivt, er sjeldent forekommende ellers i landet.» ${ }^{77}$ Deretter påpekes det at:

Befolkningen i Karasjok har i alle fall tidligere styrt den lokale ressursutnyttelsen på en sammenlignbar måte. Selv om staten etter hvert gjorde seg gjeldende og befolkningen har forholdt seg til statens disposisjoner, har den lokale bruken fortsatt et betydelig omfang. ${ }^{78}$

Videre viser kommisjonen til at de lokale oppsitterne ikke hadde norsk som morsmål, og at det ved vurderingen dermed må legges vekt på at en stor del av befolkningen på denne tiden behersket norsk dårlig. Det blir deretter vist til at det i Svartskog-dommen [129] ble tatt hensyn til at det i kommunikasjon mellom nordmenn og samer kunne oppstå misforståelser fordi språklige og kulturelle forskjeller kunne medføre at man oppfattet hverandre på en uriktig måte. ${ }^{79}$ Tilsvarende betraktninger kan anføres for Karasjok hvor hovedtyngden av befolkningen heller ikke her hadde norsk som morsmål:

Det kan derfor ikke anses avgjørende at karasjokbefolkningen har søkt om kjøp eller feste av grunn i samsvar med de ulike jordsalgslovene, eller inngått andre kontrakter med staten. Dette er ikke nødvendigvis en aksept av statens grunneierrett. Det kan snarere ha vært en følge av at en forutsetning for å drive jordbruk var å søke om kjøp eller feste av jord. ${ }^{80}$

Det påpekes deretter at med unntak av skogressursene har bruken i liten grad vært undergitt statlige reguleringer utover det som har grunnlag i offentligrettslig reguleringslovgivning om

\footnotetext{
${ }^{75}$ Finnmarkskommisjonen, Rapport felt 4, bind 1, s. 201.

${ }^{76}$ Finnmarkskommisjonen, Rapport felt 4, bind 1, s. 204.

${ }^{77}$ Finnmarkskommisjonen, Rapport felt 4, bind 1, s. 204, med henv. til Rt. 2001 s. 1229 på s. 1243.

${ }^{78}$ Finnmarkskommisjonen, Rapport felt 4, bind 1, s. 204 Her bryter kommisjonen tydelig med tidligere vurderinger, se det siterte avslutningsvis i punkt 3.2 ovenfor.

${ }^{79}$ Finnmarkskommisjonen, Rapport felt 4, bind 1, s. 198, med henv. til Rt. 2001 s. 1229 på s. 1249, jf. også Rt. 2001 s. 769 (Selbu).

${ }^{80}$ Finnmarkskommisjonen, Rapport felt 4, bind 1, s. 198
} 
utnyttelsestider og redskapsbruk. Det kan etter dette ikke legges til grunn at Karasjok-folkets manglende protester mot statens disposisjoner har karakter av rettsutslettende passivitet. ${ }^{81}$

Situasjonen er imidlertid annerledes når det gjelder statens kommersielle skogsdrift. Språklige og andre forhold kan imidlertid ha bidratt til at eventuell misnøye med denne ikke har blitt uttrykt, samtidig som skogsdrift alene ikke kan gi grunnlag for erverv av eiendomsrett. Imidlertid legges det til grunn at det også må ses hen til at statens disposisjoner over grunn og ressurser i Karasjok, med unntak av årene mellom 1902 og 1965, hadde et relativt begrenset omfang, samtidig som lokalbefolkningens bruk har vært videreført fram til i dag. Dermed er det «vanskelig å se at de statlige disposisjonene kan ha medført at den retten lokalbefolkningen hadde i 1751 har falt bort. Det kan heller ikke ses at retten i vesentlig eller nevneverdig grad har endret karakter». ${ }^{82}$

Videre peker kommisjonen på at de statlige disposisjonene som etter sin art har et privatrettslig preg, har blitt utøvd på en måte som hadde preg av samfunnsmessig styring, med andre ord offentlig forvaltning. At disposisjonene var et utslag av statlig assimileringspolitikk, svekker også deres vekt:

Det må derfor legges til grunn at statens disposisjoner da Samerettsutvalget ble opprettet $\mathrm{i}$ 1980 ikke hadde brutt ned den lokale retten som var etablert i Karasjok da området ble underlagt dansk-norsk enejurisdiksjon i $1751 .{ }^{83}$ [130]

Kommisjonens flertall (Gauslaa, Henriksen og Magga) har etter dette lagt til grunn at statens disposisjoner over grunn og ressurser i utredningsområdet lenge hadde et beskjedent omfang. Mot slutten av 1800-tallet, og særlig etter at jordsalgsloven av 1902 trådte i kraft, fikk statens disposisjoner noe større omfang:

De har imidlertid ikke hatt et innhold som har kunnet etablere statens eiendomsrett som et festnet rettsforhold eller på sedvanerettslig grunnlag. Disposisjonene har hatt et offentligrettslig preg, og har ikke brutt ned rettsoppfatningene om en sterk lokal kollektiv rett. De har heller ikke bidratt til å etablere en tilstrekkelig bred aksept for staten som privatrettslig grunneier hos lokalbefolkningen. ${ }^{84}$

Denne erkjennelsen leder til at flertallet konkluderer med at det ikke er tilstrekkelig med holdepunkter for at statens eiendomsrett til den usolgte grunnen i Karasjok var etablert som et festnet rettsforhold da FeFo overtok den fra Statskog SF 1. juli 2006:

\footnotetext{
${ }^{81}$ Finnmarkskommisjonen, Rapport felt 4, bind 1, s. 202.

${ }^{82}$ Finnmarkskommisjonen, Rapport felt 4, bind 1, s. 202.

${ }^{83}$ Finnmarkskommisjonen, Rapport felt 4, bind 1, s. 203.

${ }^{84}$ Finnmarkskommisjonen, Rapport felt 4, bind 1, s. 218.
} 
Denne eiendomsmassen er derfor ikke underlagt FeFos eiendomsrett etter finnmarksloven, men er kollektivt eid av lokalbefolkningen $i$ Karasjok. ${ }^{85}$

På spørsmålet om statens disposisjoner har brutt ned oppfatningene om sterke lokale, kollektive rettigheter til grunn og utmarksressurser, gir flertallet dermed samme svar som Utmarksdomstolen i Nesseby-saken. Som nevnt er dette er et spørsmål Høyesterett i plenum ikke fant å være en relevant problemstilling i den samiske kommunen Nesseby i $2018 .{ }^{86}$

Flertallet konkluder videre med at retten ikke ligger til kommunen som sådan, men til alle som til enhver tid har registrert bostedsadresse i Karasjok, og slik at disse har lik andel i retten uavhengig av botid og etnisk opprinnelse. Flertallet poengterer dessuten, med henvisning til Høyesteretts Nesseby-dom, at lokale bruksrettigheter «må respekteres». Det innebærer at eiendomsretten må utøves slik at lokale rettighetshaverne ikke fortrenges fra disse områdene.

Kommisjonens mindretall (Andersen og Heggelund) er enig med flertallet i at det $\mathrm{i} 1751$ var etablert en rettighet i Karasjok som kan minne om en kollektiv eiendomsrett. Statens senere disposisjoner i form av eiendomsutvisninger, bortforpaktninger og andre disposisjoner har imidlertid påvirket de lokale rettsoppfatningene i en slik grad at statens eiendomsrett til grunnen har blitt etablert som et festnet rettsforhold. Ifølge mindretallet har dette medført at lokalbefolkningens opprinnelige kollektive [131] rett har endret karakter og blitt erstattet av den bruksretten som i dag er regulert i finnmarksloven. Denne retten disponeres av FeFo etter reglene i finnmarksloven, men slik at FeFo må ta tilbørlig hensyn til de lokale rettighetshaverne i Karasjok for å unngå at disse fortrenges fra sine tradisjonelle bruksområder. ${ }^{87}$

\subsection{Særlig om betydningen av ILO 169 og dens gjenopprettende funksjon}

ILO-konvensjon nr. 169 om urfolk og stammefolk i selvstendige stater er ratifisert av Norge og er videre gitt en sektoriell inkorporering gjennom finnmarksloven $\S 3$, som lyder slik:

Loven gjelder med de begrensninger som følger av ILO-konvensjon nr. 169 om urfolk og stammefolk i selvstendige stater. Loven skal anvendes i samsvar med folkerettens regler om urfolk og minoriteter og bestemmelser i overenskomster med fremmede stater om fisket $\mathrm{i}$ grensevassdragene.

Høyesterett har i HR-2016-2030-A (Stjernøya) avsnitt 76 lagt til grunn at begrensningene stilt opp i $§ 3$ første punktum ikke legger føringer på den materielle delen av rettskartleggingen i Finnmark, men kun på lovens egne bestemmelser. Med andre ord har ikke ILO 169 forrang

\footnotetext{
${ }^{85}$ Finnmarkskommisjonen, Rapport felt 4, bind 1, s. 218 (uth. av kommisjonen)

${ }^{86}$ Se s. 125 og fotnote 59 på samme side.

${ }^{87}$ Finnmarkskommisjonen, Rapport felt 4, bind 1, s. 219.
} 
fremfor reglene som skal brukes for å avklare rettighetene på Finnmarkseiendommens grunn. Dette er bekreftet i HR-2018-456-P (Nesseby) avsnitt 102.

I Karasjokutredningen finner Finnmarkskommisjonen likevel grunn til å legge betydelig vekt på ILO 169 under rettskartleggingen. Bl.a. påpekes det at ILO 169 innebærer at det ikke kan stilles særlig strenge krav til befolkningens rettsoppfatninger for at rettigheter skal kunne anses etablert eller være i behold. Dette innebærer at:

Statens uttrykte eierpretensjoner vil ikke alene være nok til å frata samiske rettighetspretendenter deres gode tro, og for at etablerte rettigheter skal være brutt ned av statlige disposisjoner, må det kreves relativt mye både når det gjelder varighet, fasthet og innhold. ${ }^{88}$ Dette gjentas senere i utredningen hvor kommisjonen viser til ILO 169 artikkel 8 (1), jf. også artikkel 26 (3) i FNs erklæring om urfolks rettigheter, og uttaler at disse bestemmelsene innebærer at det i nasjonal rettsanvendelse må tas tilbørlig hensyn til [132] urfolkets sedvaner og rettsoppfatninger. ${ }^{89}$ Det innebærer at det ved anvendelsen av nasjonal tingsrett ikke kan stilles spesielt strenge krav til rettsoppfatning eller aktsom god tro for å anerkjenne et samisk rettighetserverv, og at internrettslige godtrokrav må praktiseres relativt mildt. ${ }^{90}$

Kommisjonen nytter videre ILO 169 til støtte for andre deler av sine konklusjoner. Ovenfor har vi sett at den har lagt til grunn at statens disposisjoner ikke hadde brutt ned den lokale retten som var etablert i Karasjok da området ble underlagt dansk-norsk enejurisdiksjon i 1751. En årsak til dette er at kommisjonen vektlegger at ILO 169 artikkel 14 (1) første punktum om urfolkets rett til eierskap og besittelse har en gjenopprettende funksjon. Det blir her vist til Nesseby-dommen, hvor Høyesterett uttaler at «[e]t slikt utgangspunkt må generelt sett være riktig, og har støtte i forarbeidene til ILO-konvensjon nr. 169». Det innebærer ifølge Høyesterett at «det ikke vil være avgjørende om staten eller andre gjennom en viss periode har hatt rådighet over områder som tidligere har vært benyttet av urbefolkningen». ${ }^{91}$ På grunn av de faktiske forhold som ble lagt til grunn i Nesseby-saken, der også andre grupper enn de som sognet til bygdelaget hadde utøvd langvarig bruk, og hvor statens disposisjoner angivelig

\footnotetext{
${ }^{88}$ Finnmarkskommisjonen, Rapport felt 4, bind 1, s. 186.

${ }^{89}$ I Girjas-målet (T-853-18) viser Högsta domstolen i Sverige til samme bestemmelse og påpeker (da konvensjonen ikke er ratifisert av Sverige) at den «får i denna del anses ge uttryck för en allmän folkrättslig princip. En tillämpning av denna princip vid lösandet av tvister med koppling till markrättigheter som berör samer medför alltså att en samisk sedvana som har konstaterats ska beaktas» (avsnitt 130).

${ }^{90}$ Finnmarkskommisjonen, Rapport felt 4, bind 1, s. 204. Kommisjonen har tidligere gjort en liknende betraktning vedrørende reindriftsrettigheter (Rapport felt 1, s. 48, Rapport felt 2, s. 46, Rapport felt 3, s. 100, og Rapport felt 5, s. 121) uten at det har fått praktiske følger.

${ }^{91}$ Finnmarkskommisjonen, Rapport felt 4, bind 1, s. 203, med henv. til HR-2018-456-P avsnitt 173. Den gjenopprettende funksjonen omtales også som restitusjonsprinsippet eller retten til restitusjon. Dens betydning i norsk rett er nærmere omtalt i Øyvind Ravna, «Restitusjon og gjenoppretting i norsk urfolksrett», Lov og Rett 2020, s. 566579 .
} 
hadde pågått «i flere hundre år», unnlot Høyesterett å gå nærmere inn på betydningen av denne funksjonen.

Som vi alt har sett, har kommisjonen lagt til grunn at statens disposisjoner i Karasjok ikke er like langvarige, og at de disposisjonene det i første rekke er relevant å trekke inn i vurderingen som uttrykk for eierrådighet, fant sted i perioden fra tidlig 1900-tall til noen år ut på 1970-tallet. Den fortsetter med å anføre at om den samiske bruken hadde opphørt i denne perioden, og det ikke lenger var noen forbindelse mellom den bruken som opprinnelig ble utøvd og dagens situasjon, kunne rundt 70 år etter forholdene vært tilstrekkelig (for bortfall). Formuleringen «traditionally occupy» i artikkel 14 (1) første punktum innebærer imidlertid at det ikke er et krav at urfolkets rådighetsutøvelse og bruk må ha pågått med samme omfang og samme innhold som den opprinnelig gjorde, for å utløse retten til eierskap og besittelse etter [133] artikkel 14. ${ }^{92}$ Det vises her til at Samerettsutvalgets folkerettsgruppe mente at for å oppfylle vilkåret om «traditionally occupy» ville det være tilstrekkelig «om den bruk som påberopes som grunnlag for retten», har stått ved lag til noen år inn på 1900-tallet, ${ }^{93}$ og at Justisdepartementet i forkant av Norges ratifikasjonen av ILO 169 antok at situasjonen måtte ha vedvart «fram til våre dager». ${ }^{94}$

Kommisjonen anfører deretter at det neppe er påkrevd å gå nærmere inn på dette:

På samme måte som i spørsmålet om det foreligger et festnet rettsforhold eller en sedvanerettsdannelse, vil dette [spørsmålet om eiendomsrett] bero på en helhetsvurdering. Det er imidlertid på det rene at karasjokbefolkningens bruk har vært dominerende frem til de første tiårene etter andre verdenskrig». ${ }^{95}$

Som nevnt, legges det til grunn at befolkningen, med unntak av skogen, også betydelig grad har styrt den lokale ressursutnyttelsen.

Videre heter det at de lokale rettsoppfatningene om at retten til grunn og utmarksressurser ligger til lokalbefolkningen og ikke til staten, fortsatt står sterkt. Det betyr ifølge kommisjonen at:

Den usolgte grunnen i Karasjok må derfor anses omfattet av kriteriet «traditionally occupy» i artikkel 14 nr. 1 første punktum. Bestemmelsens gjenopprettende funksjon må innebære at rundt 70 års forholdsvis omfattende statlig rådighetsutøvelse fra rundt 1900 ikke vil være

\footnotetext{
${ }^{92}$ Finnmarkskommisjonen, Rapport felt 4, bind 1, s. 204, med henv. til ILO, Indigenous \& Tribal Peoples' Rights in Practice - A Guide to ILO Convention No. 169, 2009, s. 94-95.

${ }^{93}$ Finnmarkskommisjonen, Rapport felt 4, bind 1, s. 204, med henv. NOU 1997: 5 s. 49-50.

${ }^{94}$ Finnmarkskommisjonen, Rapport felt 4, bind 1, s. 204, med henv. til St. prp. nr. 102 (1989-90) s. 6.

${ }^{95}$ Finnmarkskommisjonen, Rapport felt 4, bind 1, s. 204.
} 
tilstrekkelig til at statens disposisjoner over grunn og ressurser har brutt ned den retten som forelå i $1751 .{ }^{96}$

Det heter videre at dette må også bli resultatet dersom man i tillegg til statens disposisjoner i denne perioden også ser hen til vel 40 år med nokså begrenset rådighetsutøvelse før 1900 og snaut 10 år fram mot 1980 med disposisjoner som har mindre vekt grunnet innsigelsene mot statens eiendomsrett. Kommisjonen peker videre på at når spørsmål om statlig eiendomsrett til et tradisjonelt urfolksområde er etablert som et festnet forhold eller på sedvanerettslig grunnlag, må det kreves relativt mye før det kan legges til grunn at urfolkets rettsoppfatning er brutt ned og erstattet av en aksept av statens eierrett: [134]

Som også flertallet i Rettsgruppen legger til grunn, må det som hovedregel foreligge en «samstemmig oppfatning» av et rettsforhold fra begge sider gjennom lang tid som grunnlag for et festnet rettsforhold [...] i Karasjok har det ikke foreligget en slik samstemt rettsoppfatning over tilstrekkelig lang tid..$^{97}$

Det framgår ikke direkte om Finnmarkskommisjonen har anvendt ILO 169 i medhold av finnmarksloven $\S 3$ første punktum, eller presumsjonsprinsippet i norsk rett. Dette har neppe praktisk betydning, og uansett synes kommisjonen å ha anvendt konvensjonen på en folkerettslig forsvarlig måte, slik at Norges forpliktelser etter artikkel 14 (1) i konvensjonen er blitt oppfylt.

\section{Drøfting}

\subsection{Det rettshistoriske faktum}

I Karasjokutredningen er det rettshistoriske materialet underlagt en grundigere og mer spørrende analyse enn i tidligere utredninger, noe som kanskje skyldes at kommisjonen etter hvert i større grad har fått nyttet historikeren som den ansatte i 2013. Eksempelvis gjennomgås 1500-, 1600- og 1700-tallets siida-ordninger i datidens Finnmarkssamfunn, hvor det pekes på at «innbyggerne i de samiske fjordstrøkene [som sorterte under norske tingsteder] i stor grad hadde enerett til ulike ressurser i sine områder». ${ }^{98}$ Det pekes deretter på at «[s]vensk lovgivning, domspraksis og administrativ praksis bidro [...] til at rettsutviklingen

\footnotetext{
${ }^{96}$ Finnmarkskommisjonen, Rapport felt 4, bind 1, s. 204.

${ }^{97}$ Finnmarkskommisjonen, Rapport felt 4, bind 1, s. 204, med henv. til NOU 1993: 34 s. 264 (uth. av kommisjonen).

${ }^{98}$ Finnmarkskommisjonen, Rapport felt 4, bind 1, s. 31, med henv. til Allan Kristensen, «Samiske sedvaner og rettsoppfatninger - med utgangspunkt i studier av tingbøkene fra Finnmark for perioden 1620-1770», i NOU 2001: 34 s. 33-37 og 47-48.
} 
i Indre Finnmark fra rundt 1550 til 1750 ble annerledes enn ved kysten». ${ }^{99}$ Forskjellene mellom dansk-norsk og svensk suverenitet synes likevel ikke å influere i avgjørende grad på vurderingen av de faktiske historiske forholdene.

Kommisjonen stiller også det høyst relevante spørsmål om Kongens angivelige avhendinger av allmenningsjord til boplasser, virkelig skjedde i kraft av en opprinnelig eiendomsrett til den avhendede grunnen, hvor det mer enn antydes at avhendingene heller var utslag av en styringsrett med grunnlag i et kongelig privilegium. ${ }^{100}$ [135]

Den historiske gjennomgangen har bl.a. ledet til en erkjennelse av at statens disposisjoner i sitt innhold har vært mindre omfattende enn tidligere antatt. Dette er ikke alene et resultat av at utredningsområdet lenge lå under svensk jurisdiksjon; det er like mye et resultat av arbeidet som er lagt ned i studien, og som har avdekket at statens disposisjoner i liten grad har bestått av eierrådighet. Resultatet har således relevans utenfor felt 4, og har bidratt til å fylle «huller» i tidligere utredninger. I motsetning til i tidligere rapporter legges det også til grunn at lokalbefolkningen hadde rettigheter som kan sammenliknes med eiendomsrett på 1600- og 1700-tallet. Dette innebærer som vist at kommisjonen spør om denne retten er i behold, ikke om lokalbefolkningen gjennom bruk i god tro har opparbeidet en slik rett.

\subsection{Vekten på statens disposisjoner og lokal ressursforvaltning}

Flytter man seg over på de rettslige vurderingene, har det skjedd en endring både når det gjelder vekten på de statlige disposisjonene som er dokumentert i perioden fra $1751 \mathrm{og}$ fram til i dag, og i vurderingen av lokalbefolkningens uformelle ressursforvaltning. Selv om kommisjonen tar utgangspunkt $i$ at statens disposisjoner skal vurderes på «vanlig måte», tar den i betydelig grad inn over seg kritikk den har blitt møtt med i tidligere utredninger, ${ }^{101}$ og har dermed moderert vekten den tidligere har lagt på statens disposisjoner. I de fem forutgående utredningene var de statlige disposisjonene og statens tidligere eierrådighet langt på vei avgjørende for at kollektiv eiendomsrett eller styringsrett over lokale naturgoder ikke ble anerkjent. I Karasjokrapporten reduseres relevansen av disse disposisjonene, ved i mindre grad å betrakte dem som eierrådighet, i slik grad at de ikke tillegges vesentlig rettsskapende betydning. Selv om det i perioden 1811 til 1814 ble oppmålt og skyldsatt ti eiendommer i

\footnotetext{
${ }^{99}$ Finnmarkskommisjonen, Rapport felt 4, bind 1, s. 32, med henv. til Otto Jebens, Om eiendomsretten til grunnen $i$ Indre Finnmark, 1999, s. 144-152, og Sverre Tønnesen, Retten til jorden i Finnmark, 1972, s. 104-114.

${ }^{100}$ Finnmarkskommisjonen, Rapport felt 4, bind 1, s. 198-199. Se for $\emptyset$ vrig note 72 ovenfor, hvor det både er vist til hjemmelen for Kongens styringsrett, og til at det nok heller var jorddeling, framfor avhending, som fant sted.

${ }^{101}$ Se bl.a. note $70 \mathrm{og}$ «Report of the Special Rapporteur on the rights of indigenous peoples on the human rights situation of the Sami people in the Sápmi region of Norway, Sweden and Finland», 9. august 2016, avsnitt 23 og 24.
} 
Ávjovárri/ Karasjok, ${ }^{102}$ noe som er tidlig i finnmarksk sammenheng, ${ }^{103}$ vektlegges [136] ikke dette som statlig eierrådighet, men som formalisering av etablert bruk. Det er ingen grunn til å anta at dette ikke er en treffende rettshistorisk vurdering. ${ }^{104}$

Samtidig er dette er en vurdering som i betydelig grad avviker fra hvordan slike disposisjoner er blitt vurdert tidligere. Også statens disposisjoner etter 1863 vurderes i et nytt lys. Selv om det påvises 144 jordutmålinger i Karasjokfeltet i perioden 1863 til 1902, vurderes dette som formalisering av etablert bruk framfor statlig eierrådighet. ${ }^{105}$ Utmålingene mellom 1902 og 1965, som teller 770 tilfeller, vektlegges i sin tur i begrenset grad som følge av den gjenopprettende funksjonen eller restitusjonsregelen i ILO 169 artikkel 14.

At det i større grad ses på statens privatrettslige rådighetsutøvelse over grunn som ikke har vart utmålt og solgt til private, viser også et endret fokus. Når kommisjonen anfører at statens disposisjoner i Karasjok ikke er like langvarige som i eksempelvis Nesseby eller Varanger-feltene, er det heller et resultat av endrede vurderinger enn en faktisk realitet.

Det er således ikke bare det man kan se på som bevisvurderinger, som er endret. Også de rettslige spørsmålene blir stilt på en annen måte idet kommisjonen tar utgangspunkt i bygdefolkets rettigheter og spør om denne retten er $i$ behold, eller om statens disposisjoner og antatte eiendomsrett fra 1751 fram til 1980 tilsier at staten var grunneier fram til grunnen ble overført til FeFo. Som nevnt har Høyesterett tidligere ikke vurdert dette som et treffende. Med den tydelige gjennomgangen av det historisk faktum i saken kan dette likevel ikke være en uriktig tilnærming. ${ }^{106}$

\footnotetext{
${ }^{102}$ Finnmarkskommisjonen, Rapport felt 4, bind 1, s. 164.

${ }^{103}$ Det har lenge vært kjent at det på kysten av Vest-Finnmark ble oppmålt og skyldsatt et betydelig antall eiendommer i perioden 1775 til 1789, se Lars Hess Bing, Beskrivelse over Kongeriget Norge, Øerne Island og Farøerne, samt Grønland, Kiøbenhavn 1796, s. 147. I det Øvrige fylket er det annerledes. Statens første kjente «jordutvisning» i felt 2 Nesseby er ifølge Finnmarkskommisjonen datert 1824, og oppmåling av eiendommer fikk først et visst omfang her i 1830, se Finnmarkskommisjonen, Rapport felt 2, s. 66. I felt 5 Varanger øst fant den første «jordutvisningen» (i Vads $\varnothing$ ) sted i 1841 og i Vardø i 1844, se Rapport felt 5, s. 55. Finnmarkskommisjonen viser for $\emptyset$ vrig (samme sted) til at det i amtmannsberetningen fra Finnmark 1836-40 heter: «Jordutdelingen efter Resolutionen av 27de Mai 1775 endnu kun er for en Deel fremmet i Lebesby og Kjøllefjord, Thanens og Næsseby Thinglaug, men aldeles ikke i Vadsø, Vardø og Polmak Thinglauge.» I Berlevåg kommune i felt 6 ble det etablert to eiendommer i dagens Berlevåg i 1817, mens det i Båtsfjord ikke fant sted utvisning av jord før i 1864, Rapport felt 6, s. 61.

${ }^{104}$ Se note 72 ovenfor.

${ }^{105}$ Sammenliknet med det forutgående feltet, felt 6, er dette ikke lave tall. Av Rapport felt 6, s. 61, fremgår det at omfanget av oppmålingene i Båtsfjord og Berlevåg er sammenliknbare på 1800-tallet. For felt 2 Nesseby finner vi ikke like detaljerte opplysninger om oppmålinger av eiendommer. Det heter likevel (s. 66) at «[s]amlet sett fremstår det imidlertid som klart at statens pretensjon om å være privatrettslig eier av grunnen Nesseby har kommet klart til uttrykk gjennom en periode som langt overstiger 100 år».

${ }^{106}$ Det kan her vises til at Tønnesen, Retten til jorden i Finnmark, Bergen 1972, s. 183, skriver at det ikke er lokalbefolkningens rettsoppfatning (om særrettigheter av gammel dato) som må unders $\emptyset$ kes, «men om statens bruk som eier har vært av en så massiv karakter at bygdelagenes særrettigheter ble mothevdet eller frihevdet». For at det kunne skje, skriver Tønnesen (samme sted) må «man vel [...] kreve at staten har opptrådt $i$ strid med befolkningens interesser forat bygdene skal ha tapt sin rett» (uth. av Tønnesen).
} 
Kommisjonen har videre vært tydelig på at statens disposisjoner etter 1980 ikke er relevante. Dette begrunnes i at det da ble stilt spørsmål ved statens eiendomsrett, noe som utgjør en fristavbrytende omstendighet som vil «danne en ytre ramme for hvilke statlige disposisjoner det er relevant å trekke inn i vurderingen av dagens rettighetsforhold». ${ }^{107}$ For de tidligere feltene er det ikke stilt opp en slik omstendighet.

Finnmarkskommisjonen finner videre at lokalbefolkningen i Karasjok har utøvd betydelig grad av styring og forvaltning, noe kommisjonen ikke har funnet at har [137] skjedd i tidligere felter, tross liknende naturbruk og resursfordeling. For felt 5 Varangerhalvøya øst ble slik lokal sedvaneforankret forvaltning redusert til «minnelige ordninger» og «uformelle fordelingsordninger». ${ }^{108}$ I tillegg vektlegges det at befolkningen i betydelig grad har vært samisktalende, ${ }^{109}$ noe som også er tilfellet i felt 2 Nesseby, uten at det ble tillagt tilsvarende vekt.

Med den reduserte vekten på statens disposisjoner, som i liten grad er et resultat av at statlige disposisjoner rent faktisk har vært vesentlig mindre i felt 4 enn i tidligere felt, men heller at de er vurdert på andre måter og da i særlig i mindre grad som eierbeføyelser, er en viktig skranke for å anerkjenne bygdefolks kollektive eiendomsrett fjernet. Og ved samtidig å anerkjenne den lokale ressursforvaltningen som reell styring er kommisjonen i stand til å identifisere en lokal eierrådighet og eieroppfatning som tilsier at lokalbefolkningen var eiere til sine utmarksområder da områdene ble overdratt til Finnmarkseiendommen i 2006. Nedenfor skal vi se at anvendelsen av ILO 169 også utgjør et bidrag til dette.

\subsection{Vekten på ILO 169}

Finnmarkskommisjonen har i Karasjokutredningen funnet å vektlegge ILO-konvensjon nr. 169 i slik grad at det har påvirket dens konklusjoner. Dette har den ikke gjort i tidligere utredninger, og det fremstår også som noe uventet, sett i forhold til at Høyesterett, som vist ovenfor, har tolket betydningen av inkorporeringen av ILO 169 til kun å innebære at den har forrang framfor finnmarkslovens bestemmelser.

Finnmarkskommisjonen har bl.a. vektlagt ILO 169 som tolkningsfaktor, og dermed som et argument for å tilpasse kravene om rettsoppfatninger og «god tro» til en folkerettslig standard. Minst like viktig er det at kommisjonen har vektlagt den gjenopprettende funksjonen i artikkel 14 (1), noe som er en følge av Høyesteretts erkjennelse i Nesseby-dommen av denne

\footnotetext{
${ }^{107}$ Finnmarkskommisjonen, Rapport felt 4, bind 1, s. 184 og 187. Det vises for øvrig (på s. 188) til at et slik ytterpunkt for å vektlegge statens disposisjoner kunne vært satt til tidligere tidspunkt.

${ }^{108}$ Finnmarkskommisjonen, Rapport felt 5, s. 58.

${ }^{109}$ Finnmarkskommisjonen, Rapport felt 4, bind 1, s. 198.
} 
funksjonens eksistens, og som bidrar til å redusere betydningen av statens disposisjoner på 1900-tallet. Samlet gjør dette at ILO 169 får reell, om ikke nødvendigvis materiell, betydning for rettskartleggingen i Karasjokfeltet. Kommisjonen har her anvendt den avklaring Høyesterett gjør av den gjenopprettende funksjonens eksistens ved denne anvendelsen av ILO 169, noe som utvider de noe snevre rammene Høyesterett har stilt opp når det gjelder konvensjonens rekkevidde i Stjernøya-dommen. ${ }^{110}$ [138]

Rettsanvendelsen til kommisjonen vil trolig etablere en praksis som kan innebære at ILO 169 vil få en større betydning i rettskartleggingen i tiden fremover enn det den hittil har hatt.

\subsection{Betydningen av svensk overhøyhet før 1751}

Svensk overhøyhet over tvisteområdet fram til 1751 er noe av det som skiller Karasjokfeltet tydeligst fra andre samiske områder som er utredet, slik som Nesseby-feltet og Gulgofjordområdet i felt 6. Kommisjonen har imidlertid i liten grad forankret sin konklusjon i at Karasjokområdet har vært underlagt svensk overhøyhet fram til 1751. Dog kan man anta at den noe mindre observerte statlige aktiviteten et stykke på vei kan forklares slik, men uten at det er påtrengende synlig. Samtidig må det spørres om konklusjonene er et resultat av at utredningsfeltet er lokalisert til Indre Finnmark, og at man har lagt vekt på den tradisjonelle oppfatningen om at dette er et samisk kjerneområde, i motsetning til kysten og de sjøsamiske bruksområdene som er blitt fornorskede og dermed norske. Finnmarksloven og Finnmarkseiendommen er nettopp forankret i en slik forståelse, noe som fremgår av Samerettsutvalgets drøfting i NOU 1997: 4 og forslaget om et felles styre for Finnmark Grunnforvaltning med lik representasjon for Sametinget og Finnmark fylkesting. Denne styresammensetningen er grunnet i en oppfatning om at samene, i samsvar med ILO 169 artikkel 14 (1), har rett til å eie sine tradisjonelle landområder, og at det er gjort et «makeskifte» hvor samene får $50 \%$ av eiendomsretten til hele Finnmark mot å avstå $50 \%$ av eiendomsretten til Indre Finnmark. ${ }^{111}$

Det er imidlertid ikke grunn til å anta at dette har motivert kommisjonen. Realiteten, som Finnmarkskommisjonen selv har bidratt til å avdekke i Karasjokutredningen, er nettopp at selv om Kyst-Finnmark har vært under norsk overhøyhet lenger enn Indre Finnmark, er ikke

\footnotetext{
${ }^{110}$ Det må her også pekes på at Utmarksdomstolen, i UTMA-2017-62459, 10. oktober 2018 (Gulgofjord), tross ulikt faktum, hvor den sjøsamiske befolkningen i området, på samme måte som folket i Karasjok, nokså sikkert oppfylte vilkåret om «traditionally occupy» artikkel 14 (1), ikke fant noe rom for å modifisere godtro-kravet, å vektlegge statens disposisjoner i mindre grad, eller å vektlegge restitusjonsprinsippet.

${ }^{111}$ NOU 1997: 4 s. 90 («makeskiftesynspunkt») og s. 170. Se også redegjørelsen om dette i punkt 2.1 ovenfor.
} 
de statlige grunneierdisposisjonene av eldre dato der enn i Karasjok. Generelt sett er det lite sannsynlig at slike disposisjoner har funnet sted noen plass i Finnmark før 1863. ${ }^{112}$ [139]

\section{Avslutning}

Finnmarkskommisjonen har i Karasjokutredningen vurdert det rettshistoriske faktum på en nyansert måte. Og selv om resultatet er et annet enn i tidligere utredninger (og i Høyesteretts Stjernøya- og Nesseby-dom), har den utvilsomt anvendt rettsreglene godt innenfor rammene av gjeldende norsk og det mandat kommisjonen er tildelt. At rapportens hovedkonklusjon er framlagt under dissens, endrer ikke på dette. Kommisjonen vektlegger her Norges folkerettslige forpliktelser overfor samene i ILO 169 artikkel 14 (1) om å anerkjenne «vedkommende folks eiendoms- og råderett til de landområder som de tradisjonelt besitter» på en måte som gjør at konvensjonen har fått reell betydning ved rettskartleggingen. Dette har samtidig medført at den nok kan ha utfordret Høyesteretts forståelse av ILO 169s rekkevidde i Stjernøya-dommen noe.

Høyesterett har imidlertid lagt til grunn at den gjenopprettende funksjonen, det såkalte restitusjonsprinsippet, utgjør en del av ILO 169 artikkel 14 og således har en plass i norsk rett. Høyesterett har også uttalt at ILO 169 har vesentlig betydning uavhengig av inkorporeringen gjennom finnmarksloven, både som følge av finnmarksloven $\S 3$ annet punktum og det alminnelige presumsjonsprinsippet. ${ }^{113}$ Dette gjør at kommisjonens rettsanvendelse nettopp følger normene Høyesterett har trukket opp i Nesseby-dommen.

Finnmarkskommisjonens rettsanvendelse har bidratt til å gi ILO $169 \varnothing \mathrm{kt}$ relevans og betydning for rettskartleggingen, slik som forutsatt av flertallet i Stortingets justiskomité. ${ }^{114}$ Kommisjonen kan på denne måten, kanskje i like stor grad som Høyesterett, ha bidratt til å etablere en praksis til etterfølgelse også for domstolene.

Den kursjustering som Finnmarkskommisjonen har gjort, har samtidig vært nødvendig for at den skulle kunne bidra til Norges folkerettslige forpliktelser på dette området. Det har trolig også styrket dens legitimitet i det samiske samfunnet. Justeringen har også bidratt til at alders

\footnotetext{
${ }^{112}$ Det første jordsalget i Finnmark fant sted i medhold av lov 22. juni 1863 om Afhændelse av Statens Jord i Finmarkens Landdistrict, som for øvrig også er den første loven som nytter betegnelsen «statens jord» eller «statens grunn», se Gudmund Sandvik, «Statens grunn i Finnmark. Et historisk perspektiv», i NOU 1993: 34 Rett til og forvaltning av land og vann i Finnmark, s. 334-380 på s. 337. Jorddelingsresolusjonen av 1775 initierte sannsynligvis jorddeling (oppløsing av fellesskap) og ikke jordsalg, se note 72 ovenfor.

${ }^{113}$ HR-2019-456-P (Nesseby) hhv. avsnitt 173 og 103 (gjentatt i 166). At Høyesterett ikke anvendte restitusjonsprinsippet, skyldes en vekt på faktiske forhold (avsnitt 138) som kommisjonen ikke slutter seg til, se Rapport felt 4, bind 1, s. 37.

${ }^{114}$ Innst. O. nr. 80 (2004-2005) s. 28.
} 
tids bruk-reglene i større grad blir anvendt i tråd med et faktum som reflekterer de historiske realitetene i Finnmark, og videre til en samisk kontekst, slik det er gjort i Rt. 2001 s. 769 (Selbu) og Rt. 2001 s. 1229 (Svartskogen). Samtidig vil det nok fra annet hold (enn det samiske) og fra parter i tidligere utredninger, kunne reises spørsmål ved tidligere praksis og forutsigbarheten i utredningsarbeidet. [140]

Utfordringene som avgjørelsen reiser, ligger på det politiske og forvaltningsmessige plan. Selv om regjering og Stortinget har forutsatt at hele den tidligere statsgrunnen i Finnmark ikke nødvendigvis vil være eid av FeFo etter at rettskartleggingen er fullført, ${ }^{115}$ har de ikke foreslått eller vedtatt ordninger for forvaltningen av utmark som ikke vil være eid av FeFo. Dette vil kreve en stødig hånd både for grunneiere som får anerkjent sin rett, for FeFo, og trolig også for så vel lokale og regionale politikere som lovgivende myndighet. ${ }^{116}$

Dette er imidlertid ikke en for stor utfordring; det finnes praksis og regelverk å hente både fra fjellstyrene, forvaltningen av bygdeallmenningene og ikke minst i delene av Samerettsutvalgets forslag som ikke ble videreført av regjeringen Bondevik og således aldri framlagt for Stortinget. Videre kan det også vises til forvaltningen av Svartskogen, hvor folk i Manndalen i Kåfjord kommune fikk anerkjent eiendomsretten til et område staten lenge hadde oppfattet seg som eier av. Her har man fått til en funksjonell bygdeallmenningsmodell som kan stå som eksempel for de områdene i Finnmark hvor det etter hvert kan bli avdekket lokalt eierskap.

\section{Kilder}

\section{Litteratur}

Bing, Lars Hess, Beskrivelse over Kongeriget Norge, Øerne Island og Farøerne, samt Grønland, Kiøbenhavn 1796.

Bull, Kirsti Strøm, Finnmarksloven - Finnmarkseiendommen og kartlegging av rettigheter i Finnmark, Lov og Rett 2007, s. 545-560.

Falkanger, Thor, Almenningsrett, Oslo 2009.

Graver, Hans P. og Geir Ulfstein, Folkerettslig vurdering av forslaget til ny Finnmarkslov, 3. nov. 2003.

Helland, Amund, Norges land og Folk: Finmarkens Amt, bind II, Oslo 1906.

Jebens, Otto, Om eiendomsretten til grunnen i Indre Finnmark, Oslo 1999.

\footnotetext{
${ }^{115}$ Innst. O. nr. 80 (2004-2005) s. 18.

${ }^{116}$ Den 25. november vedtok styret for FeFo i sak 75/2020, med styreleders dobbeltstemme, å si seg

enig i Finnmarkskommisjonens hovedkonklusjon. Det er ikke rom for å drøfte betydningen av vedtaket her.
} 
Nilsen, Øystein, Varangersamene: bosetning, naring, folketall, utmarksbruk mv. fra historisk tid til i dag, vol. 5 i Varanger Samiske Museums skrifter, Varanger samiske museum 2009.

Kristensen, Allan, Samiske sedvaner og rettsoppfatninger - med utgangspunkt i studier av tingbøkene fra Finnmark for perioden 1620-1770, i NOU 2001: 34 Samiske sedvaner og rettsoppfatninger. [141] Prestbakmo, Hans, Bruken av utmarksressursene i Finnmark i dette århundret, i NOU 1994: 21 Bruk av land og vann i Finnmark i historisk perspektiv.

Ravna, Øyvind, Retten til jorden i Finnmark, samenes rettigheter og forslaget til Finnmarkslov, Kritisk juss 2005, s. 200-211 på s. 205.

Ravna, Øyvind, Rettskartleggingen i Finnmark og reglene om alders tids bruk, Tidsskrift for Rettsvitenskap 2015, s. 53-90.

Ravna, Øyvind, Same- og reindriftsrett, Oslo 2019.

Ravna, Øyvind, Den tidligere umatrikulerte grunnen i Finnmark: Jordfellesskap fremfor statlig eiendom? Tidsskrift for Rettsvitenskap 2020, s. 219-263.

Ravna, Øyvind, «Restitusjon og gjenoppretting i norsk urfolksrett», Lov og Rett 2020, s. 566-579. Sandvik, Gudmund, «Statens grunn i Finnmark. Et historisk perspektiv» i NOU 1993: 34 Rett til og forvaltning av land og vann i Finnmark s. 334-380.

Steinsholt, Håvard, Oreigning, i Hans Sevatdal, v/Per Kåre Sky og Erling Berge (red.), Eigedomshistorie. Hovudliner i norsk eigedomshistorie frå 1600-talet fram mot nåtida, Oslo 2017. Tønnesen, Sverre, Retten til jorden i Finnmark. Rettsreglene om den såkalte «Statens umatrikulerte grunn»-en undersøkelse med sarlig sikte på samenes rettigheter, Bergen 1972, 2. utg. 1979.

Lover, lovforarbeider, offentlige utredninger og andre offentlige dokumenter

Finnmarkskommisjonen, Rapport felt 1 Stjernøya / Seiland, 2012.

Finnmarkskommisjonen, Rapport felt 2 Nesseby, 2013.

Finnmarkskommisjonen, Rapport felt 3 Sørøya, 2013.

Finnmarkskommisjonen, Rapport felt 5 Varangerhalvøya øst, 2014.

Finnmarkskommisjonen, Rapport felt 6 Varangerhalvøya vest, 2015.

Finnmarkskommisjonen, Rapport felt 4 Karasjok, bind 1, 2019.

FNs erklæring om urfolks rettigheter, 13. september 2007 (A/61/PV.107).

Forpaktningsbrev nr. 150, J.no 6767 1901, approbert 1. nov. 1901, framlagt av Finnmarkseiendommen for Finnmarkskommisjonens utredning av felt 2 Nesseby.

Forskrift 17. juni 2005 nr. 657 om forvaltningsområdet for samisk språk.

ILO-konvensjon nr. 169 om urfolk og stammefolk i selvstendige stater, 20. juni 1989.

ILO, Indigenous \& Tribal Peoples' Rights in Practice - A Guide to ILO Convention No. 169, 2009.

Innst. O. nr. 80 (2004-2005) Om lov om rettsforhold og forvaltning av grunn og naturressurser i

Finnmark fylke (Finnmarksloven). [142]

Justisdepartementet v/statsråden, brev til justiskomiteen, 14. juni 2004, i Innst. O. nr. 80 (2004-2005). 
Kgl.res. 27. mai 1775 angaaende Jorddelingen i Finmarken samt Bopladses Udvisning og Skyldlægning sammesteds.

Lov 22. juni 1863 om Afhændelse av Statens Jord i Finmarkens Landdistrict (opphevet).

Lov 22. mai 1902 nr. 7 om Afhændelse af Statens Jord og Grund i Finmarkens Amts Landdistrict (opphevet).

Lov 12. mars 1965 om statens umatrikulerte grunn i Finnmark fylke (opphevet).

Lov 6. juni 1975 nr. 31 om utnytting av rettar og lunnende m.m. i statsallmenningane (fjellova).

Lov 17. juni 2005 nr. 85 om rettsforhold og forvaltning av grunn og naturressurser i Finnmark (finnmarksloven).

Lov 15. juni $2007 \mathrm{nr}$. 40 om reindrift (reindriftsloven).

Lov 21. sep. $2012 \mathrm{nr}$. 66 om endringar i deltakerloven, havressurslova og finnmarksloven

NIKU, Felt 1 Stierdná/Stjernøya og Sievju/Seiland Oppdragsrapport 42 (2011) og

NIKU, Felt 2 Unjárgga gielda / Nesseby kommune, Oppdragsrapport 43 (2011).

NOU 1984: 18 Om samenes rettsstilling.

NOU 1993: 34 Rett til og forvaltning av land og vann i Finnmark

NOU 1997: 4 Naturgrunnlaget for samisk kultur.

NOU 1997: 5 Urfolks landrettigheter etter folkerett og utenlandsk rett.

NOU 2007: 13 Den nye sameretten.

Ot.prp. nr. 53 (2002-2003) Om lov om rettsforhold og forvaltning av grunn og naturressurser i

Finnmark fylke (Finnmarksloven).

Report of the Special Rapporteur on the rights of indigenous peoples on the human rights situation of the Sami people in the Sápmi region of Norway, Sweden and Finland, 9. august 2016

(A/HRC/33/42/Add.3).

\section{Rettspraksis}

Høyesterett: Rt. 2001 s. 769 (Selbu), Rt. 2001 s. 1229 (Svartskogen), HR-2016-2030-A (Stjernøya) og HR-2018-456-P (Nesseby).

Utmarksdomstolen for Finnmark: UTMA-2017-62459 (Gulgofjord).

Högsta domstolen (Sverige): T-853-18 (Girjas). 